\title{
Eguzki-energia termikoa: etxebizitzen eskariak asetzeko erabilera anitzeko iturri-berriztagarria
}

\author{
(Solar thermal energy: a versatile \\ and renewable source to meet the building demands)
}

\author{
Ana Picallo-Perez*, Jose Maria Sala-Lizarraga, Arrate Hernandez-Arizaga \\ ENEDI ikerketa taldea. Ingeniaritza Energetiko Saila \\ Euskal Herriko Unibertsitatea. \\ Ingeniero Torres Quevedo plaza, 1zk., 48013 Bilbo, Bizkaia, Spain
}

\begin{abstract}
LABURPENA: Lan honen helburua da eguzki-kolektoreen egungo egoeraren informazioa ematea, eraikuntza-sektorean. Energia-trantsiziorako giltzarri bat da eguzki-energia termikoa, eta, horregatik, iturria ustiatzeko teknologiak eta horien funtzionamendu-tarteak ezagutu behar dira, kontuan hartuz, batez ere, Espainiako eguzki-energiaren egungo egoera eta eraikinen instalazio espezifikoak. Egun, ohiko eguzki-sistemak instalatzen badira ere, hain ohikoak ez diren beste konfigurazio batzuk ere badaude. Hori dela eta, azken urteen aurkikuntzak aintzat hartu behar dira eguzki-kolektoreen material, geometria eta fluido bero-eramaile berriak ezagutarazteko. Gainera, eguzki-sistemak elementu arkitektonikoetan integra daitezke, eta eguzki bidezko hozte-sistemen aplikazioak eta klimatizazio-sareak ere bultza daitezke. Ondorioz, eguzki-energiaren aplikazio termikoak aldakorrak eta moldagarriak direla frogatzen da, eraikuntzako edozein eskari termikorako.
\end{abstract}

HITZ GAKOAK: energia-berriztagarriak; eguzki-energia termikoa; eraikuntzan eskariak; berrikuntzak eguzki-teknologian.

ABSTRACT: The aim of this paper is to provide information on the current situation of solar collectors in the building sector. Solar thermal energy is a key for the energy transition, so it is necessary to know the technologies of exploitation of the source and its operating ranges, taking into account, especially, the current situation of solar energy in Spain and the specific installations in buildings. Although conventional solar systems are currently installed, there are other less common configurations. For this reason, the findings of recent years must be taken into account in order to introduce new materials, geometries and heating fluids for solar collectors. In addition, solar systems can be integrated into architectural elements and solar cooling applications and air conditioning networks can be promoted. Consequently, it is demonstrated that the thermal applications of solar energy are versatile and adaptable for any building thermal demand.

KEYWORDS: renewable energies; solar thermal energy; building demands; innovations in solar technology.

\footnotetext{
* Harremanetan jartzeko / Corresponding author: A. Picallo-Perez. ENEDI ikerketa taldea. Ingeniaritza Energetiko Saila Euskal Herriko Unibertsitatea. Ingeniero Torres Quevedo plaza, 1 zk. (48013 Bilbo, Bizkaia). - ana.picallo@ehu.eus - https:// orcid.org/0000-0002-1889-3586

Nola aipatu / How to cite: Picallo-Perez, Ana; Sala-Lizarraga, Jose-Maria; Hernandez-Arizaga, Arrate (2021). "Eguzki-energia termikoa: etxebizitzen eskariak asetzeko erabilera anitzeko iturri-berriztagarria». Ekaia, 41, 2021, 341-371. (https://doi.org/10.1387/ekaia.22626).

Jasotze-data: 2021, martxoak 19; Onartze-data: 2021, apirilak 12.

ISSN 0214-9753 - elSSN 2444-3581 / (c) 2021 UPV/EHU
}

cc)(i) $\ominus$ Lan hau Creative Commons Aitortu-EzKomertziala-LanEratorririkGabe 4.0 Nazioartekoa

cc. 
Ana Picallo-Perez, Jose Maria Sala-Lizarraga, Arrate Hernandez-Arizaga

\section{SARRERA}

Erreserba-fosilak agortu ahala, zailtasunak handitzen dira esplorazio- eta erauzketa-jardueretan. Gainera, herrialdeen energia-kontsumo handiek prezioak igo dituzte eta, ondorioz, jatorri berriztagarriko energia erabili beharra dago, energia-kontsumoa jaisteko eta efizientzia sustatzeko [1]. Hala ere, gaur egungo munduan, energia-iturri nagusiak erregai fosilak dira; esaterako, ikatza, petrolioa eta gas naturala. Beraz, gero eta beharrezkoagoa da eskura dauden energia berriztagarriak modu naturalean erabiltzea; bereziki, eguzki-energia. Horregatik, eguzki-energia aprobetxatzeko teknikak sustatzen dira; hala nola, prozesu termikoak edo fotovoltaikoak [2].

Bestalde, kontsumo altua dela eta, eraikin-sektorean erabateko aldaketak behar dira, epe luzera, ekipamenduak hobetzeko, kontsumo-ohiturak kudeatzeko eta energia berriztagarriak integratzeko.

\subsection{Energia-trantsizioa}

Europak sustatu du «Klima Aldaketaren eta Trantsizio Energetikoaren Lege Proiektua» [3], eta Espainiak bere gain hartu du konpromisoa: deskarbonizazio-prozesuaren bidez herrialdearen ekonomia, modernizazioa eta gizartea bultzatzea, alegia. Horrela, klima-aldaketa eta energia-trantsizioa jomugan jartzen dira, ekonomiaren eta gizartearen funtsezko bektore direlako, etorkizuna eraikitzeko eta aukera sozioekonomiko berriak sortzeko.

Legeak aldaketak bultzatu eta isurketak mugatzen ditu kontsumo-ereduetan. Helburua da ekoizpen-ereduan eta energia-sisteman modernizazioak sustatzea, eta enplegu-, negozio- eta hazkunde-aukerak eskaintzea, betiere ekonomiaren deskarbonizazio ordenatu batekin. Hala, energia-trantsizioaren ondorioz, bai energia-sisteman eta baita ekonomian ere onurak egongo dira, ekonomiaren energia-eraginkortasun sistematikoa lortuz. Zehazki, aurreikuspenen arabera, Espainiako ekonomiaren lehen mailako energia \% 3,5 hobetuko da urtero, 2030era arte; era berean, herrialdearen energia-mendekotasuna (\% 742017 an) \% 61era jaitsiko da 2030ean, ikatzeta petrolio-inportazioen beherakaden ondorioz. Ekonomia-sektore guztien oinarri nagusia teknologia berriztagarriak izango dira, ekonomia eraginkor bat lortzeko [3].

\subsection{Energia-kontsumoa eraikinetan}

Gure eguneroko bizitzan eraikin bat baino gehiago erabiltzen dugu: egoitza eta lantokia (alegia, irakaskuntza-, osasun-, kultura-, zerbitzuen eta abarren eraikinak). Eraikin horietan energia kontsumitzen da berokuntza, hozkuntza, ur bero sanitarioa, aireztapena, eta bestelako beharrizanak ase- 
tzeko. Datuen arabera, munduko kontsumoaren \% 20 kontsumitzen da eraikinetan.

Etxeen energia-eskariari dagokionez, \% 60,6 termikoa da, eta $\% 80$ baino gehiago jatorri fosileko erregaiekin asetzen da [4]. Azken urteotan, gas naturalaren kontsumoa \% 7,6 igo da, eta petrolio-produktuen eskaria, berriz, \% 10,6 jaitsi. Iturri berriztagarriek, zoritxarrez, \% 1eko hazkundea baino txikiagoa dute.

\subsection{Eguzki-energia termikoa eraikinetan}

Energia-politiken ardatz bat da energia berriztagarriak eraikinetan sustatzea. Hala ere, mundu mailan, etxebizitza-eraikinetan soilik \% 7ko energia berriztagarria integratu da, eta zerbitzu-eraikinen kasuan, berriz, ez da $\%$ 1era ere iristen [1]. Gainera, munduko energia-kontsumoaren zati handi bat bero-kontsumoa da. Beraz, energia berriztagarri termikoak sustatu behar dira (hala nola, eguzki-energia); nahiz eta mundu mailan soilik \% 0,3 aprobetxatzen den [5].

Eguzki-energia termikoa ur bero sanitarioa (UBS) lortzeko erabiltzen da batik bat, eta, beraz, bere erabilera-potentziala beste energia berriztagarri batzuk baino txikiagoa da. Esaterako, biomasa berokuntzarako erabiltzen da, edo entalpia baxuko geotermia berokuntzarako eta hozkuntzarako. Hala ere, zaila da energia berriztagarri horiek hiri-espazioetan egokitzea, biomasak biltegiratzeko behar duen lekua eta geotermiaren espazio-beharra direla-eta. Eguzki-energia termikoa areagotzeko, haren funtzionamendua behar bezala ezagutu behar da; horrela diseinatu ahalko baitira baliabide hori aprobetxatzeko sistema optimoak.

Eguzki-sistema termikoak tenperaturaren arabera sailka daitezke:

- Tenperatura altuko eguzki-energia. Normalean $300^{\circ} \mathrm{C}$-tik gorako tenperaturak lortzen dira, eta elektrizitatea lortzeko erabiltzen da. Horretarako, eguzki-erradiazioa kontzentratu behar da.

- Tarteko tenperaturako eguzki-energia. $300^{\circ} \mathrm{C}$ eta $150^{\circ} \mathrm{C}$ arteko tenperaturak lortzen dira industria-sektorean, adibidez, olioa berotzeko edo aurre-beroketa prozesuetarako. Kasu honetan ere eguzki-erradiazioa kontzentratu behar da.

- Tenperatura baxuko eguzki-energia. $150^{\circ} \mathrm{C}$-tik beherako tenperaturak lortzen dira, eta UBS eta igerilekuak berotzeko erabiltzen da gehienbat; bestalde, berokuntzarako (tenperatura baxuko sistemen bidez) eta eguzki bidezko hozte-sistemetarako ere erabil daiteke. Ez da eguzki-erradiazioa kontzentratu behar, eta horregatik da aplikaziorik hedatuena.

- Eguzki-energia pasiboa. Arkitektura-soluzioak dira, non, materialak eta diseinuak behar bezala hautatuz, erradiazio intzidentearen eta 
argiztapen naturala aprobetxatzea lortzen baita, eraikinaren energiakontsumoa murriztuz. Kategoria honetan sartzen dira inertzia termikoa aprobetxatzeko horma masiboak, Trombe hormak edo fatxada aireztatuak.

\subsection{Eguzki-energia Espainian}

Espainian eguzki-instalazioak duela berrogei urte baino gehiago erabiltzen hasi ziren, eta, funtsean, bi etapa bereiz daitezke. Lehen fasean, eraikita zeuden etxeetan eguzki-instalazioak jartzea sustatu zen, eta, bigarren fasean, Eraikuntzako Kode Teknikoa (EKT) argitaratu zen. Horren arabera, eraikin berrien UBS edo igerilekua berotzeko eskariaren zati bat eguzkienergia termikoarekin asetu behar zen [6]; 2019an EKTa eguneratu egin zen, eta DB-HE4 dokumentuan arau hori aldatu zen. Bertan, UBS ekoizteko energia-berriztagarrien portzentaje minimo bat eskatzen da, eguzkienergiarekin ez ezik, edozein iturri berriztagarrirekin hornitu beharrekoa. Espainian eguzki-kolektoreak jartzeko erritmoa handia bada ere, instalatutako azalera alderatzen bada gainerako EB herrialdeekin, egoera nahiko txarra da; ikus 1. irudia [7].

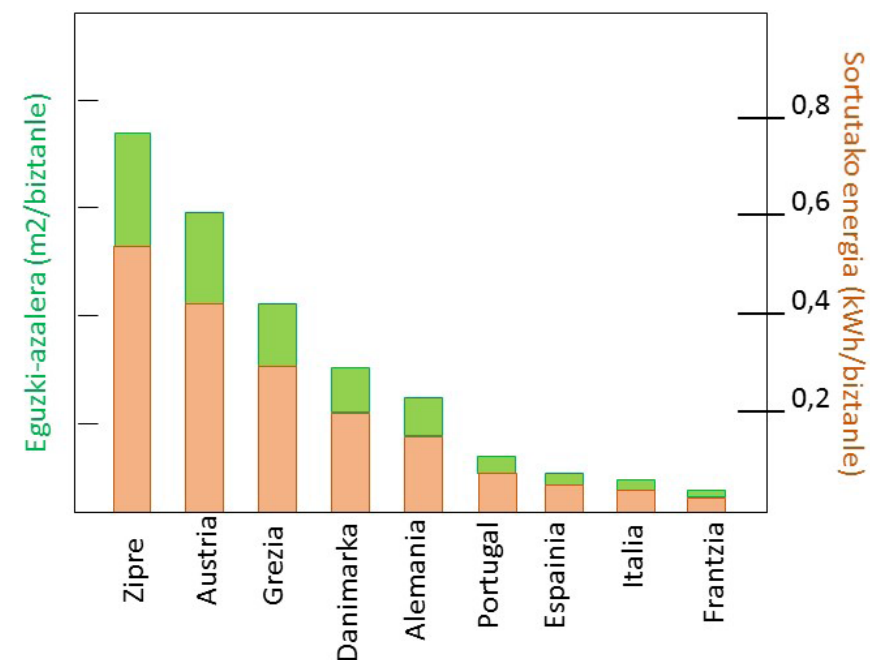

1. irudia. Eguzki-kolektore termikoen instalazioa eta biztanleko sortutako energia (2016).

Beraz, Espainia Europako erdialdeko eta iparraldeko beste herrialde batzuen atzetik dago, hala nola Alemaniaren, Danimarkaren edo Austriaren atzetik. Nazio horiek, eguzki-baliabide gutxiago izan arren, nabarmen gainditzen dute Espainiako egoera, bai instalatutako azalerari dagokionez 
eta baita eguzki-panel termikoek sortutako energiari dagokionez ere. Gainera, Espainia, Portugal edo Italia herrialdeek eguzki-irradiazio maila handia daukate, eta ez dute baliabidea aprobetxatzen. Eguzki-energia termikoaren etorkizuna, beraz, itxaropentsua da, instalazio-kostua murriztu eta aldeko araudi bat bultzatzen bada.

\section{TENPERATURA BAXUKO EGUZKI-INSTALAZIOAK}

Atal honetan, tenperatura baxuko eguzki-instalazio termikoen konfigurazio ohikoena aurkeztuko da [8].

\subsection{Eguzki-instalazio termikoen erabilera-baldintzak}

Hainbat funtzionamendu-tenperatura daude eraikinen energia-erabileretan: alegia, UBS $40-60{ }^{\circ} \mathrm{C}$ artean ekoizten da: igerileku girotuetako ura 24-30 ${ }^{\circ} \mathrm{C}$-tan; berokuntza-denboraldiko airearen tenperatura $20{ }^{\circ} \mathrm{C}$ inguruan mantendu behar da; eta hozkuntza-denboraldian, aldiz, $24{ }^{\circ} \mathrm{C}$ inguruan.

Erabilera hauek, neurri handi batean, eguzki-sistemak baldintzatzen dituzte:

- UBS eskaria konstantea izaten da urtean zehar; ikus 2. irudia a).

- Antzeko zerbait gertatzen da igerileku girotuen ura berotzean; ikus 2. irudia b).

- Bestalde, leku jakin baten berokuntza-eskaria aztertzean, fluktuazio handiagoko profila lortzen da. Berokuntza-eskaria handia da neguan; udako hilabeteetan, berriz, erabat desagertzen da. Ikus; 2. irudia c).

- Azkenik, hozkuntza-eskariak kontrako profila du. Hozkuntza-eskaerak erradiazioaren joera jarraitzen du, eta, beraz, eguzki bidezko hozte-sistema bat erabil daiteke; ikus 2. irudia d).

Eskaera denak kudeatzeko modu bat da instalazio bakar batean guztiak konbinatzea, erabilera-profilak osatuz. Hala ere, nahiz eta eguzki-kolektoreen teknologia fidagarriak eta irtenbide errentagarriak egon, honako puntu hauek hartu behar dira kontuan [6]:

- Beharrezkoa da, eguzki-instalazioak egin baino lehen, energia aurrezteko neurriak ezartzea, berokuntza- eta hozkuntza-eskariak murrizteko.

- Eguzki-ekarpen txikiko eguzki-instalazio termikoak diseina daitezke, berokuntzarik ez dagoenean, sistema laguntzailerik ez erabiltzeko. 
- Eguzki-ekarpen handiko eguzki-instalazio termikoak egiteko, irtenbide espezifikoak behar dira; hala nola, urtaroko metaketa edo berotzeko eta hozteko eguzki-girotzea.

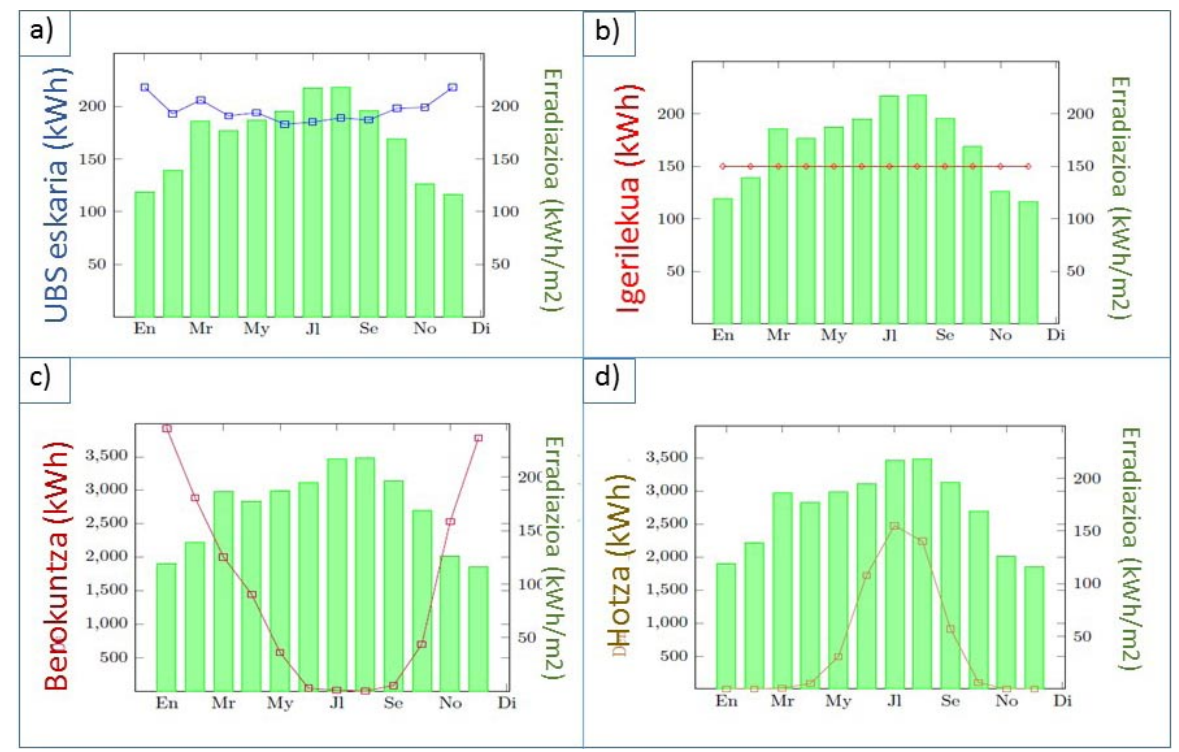

2. irudia. Eskari-profilak $v s$ eguzki-erradiazioa: a) UBS, b) igerilekua, c) berokuntza, d) hozkuntza.

Beraz, instalazio konplexuak behar dira, kontrol- eta erregulazio-sistemekin. Horregatik, gaur egun, eguzki-energia termikoko sistemak UBS ekoizteko eta igerilekuak berotzeko bideratuta daude.

\subsection{Ohiko konfigurazioak}

Energia termikoko eguzki-sistemen konfigurazio asko daude. Oro har, diseinua sinplea izan behar da, konfigurazio errazak instalazio fidagarriagoak direlako. Erabilera-profilek, kokapenak, eraikinaren konfigurazioak edo aurretiazko instalazioak mugatzen ditu konfigurazioak, nahiz eta, oro har, askatasuna egon egoera bakoitzeko konfigurazioa aukeratzeko. Nolanahi ere, konfigurazio zentralizatuak du inbertsio eta ustiapen-kostu txikiena, behar bezala gauzatzen bada. Hainbat konfigurazioa egon arren, guztiek lau elementu hauek dituzte:

- Eguzki-kolektorea. Eguzki-energia hartu eta energia termikoan bihurtzen du, normalean ura berotuz. 
- Metatze-sistema. Energia-eskaria eta eguzki-energia ez datoz denboran beti batera, eta, beraz, beharrezkoa da metatze-sistema bat, behar denean energia hornitzeko. Ohikoenak ur-tankeak dira.

- Laguntza-sistema. Eguzki-sistema termikoak eskari totala baino gutxiago emateko dimentsionatzen dira. Horrela saihesten dira eguzkisistemaren gehiegizko dimentsioak eta udako gainberotze-arazoak. Hori dela eta, laguntza-sistemak erabili behar dira, eguzki-sistemak eman ezin duen gainerako energia emateko.

- Banaketa-sistema. Energia termikoa etxe barrura hornitzeaz arduratzen da.

3. irudian eguzki-energia sistemen eskema orokorra erakusten da. Irudi horretan elementu erredundanteak agertzen dira, eta ez dira beti instalazio guztietan egon behar [8].

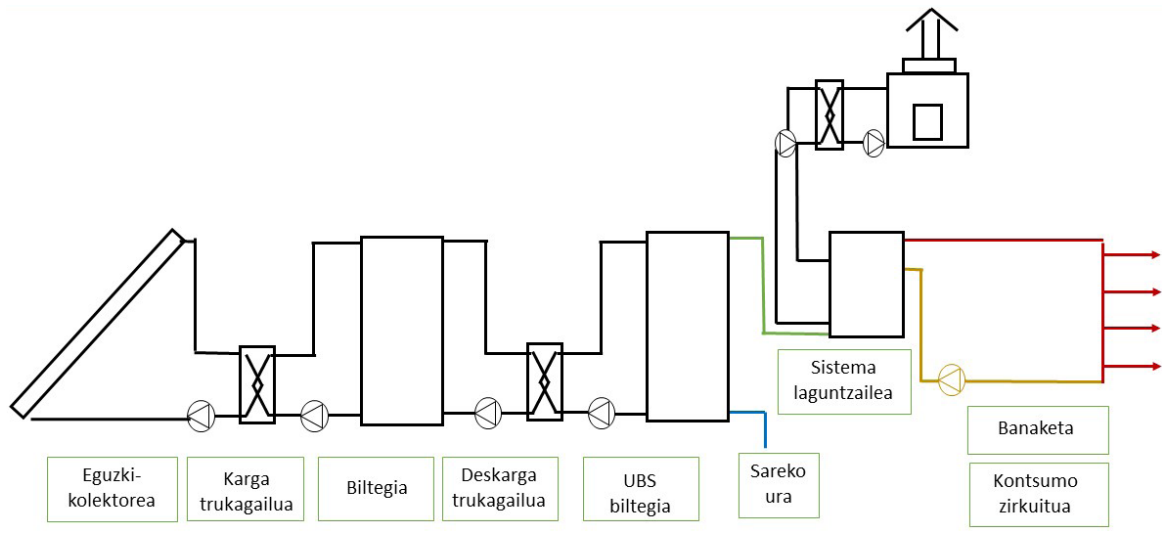

3. irudia. Eguzki-energia termikoaren eskema orokorra [8].

\section{ENERGIA-BALANTZEA ETA ETEKINA}

Eguzki-kolektorea da eguzki-instalazio baten elementu nagusia. Termodinamikoki, hau da eguzki-kolektore baten oinarrizko funtzionamendua:

— «A» azalerako kolektoreko beirari «GA» eguzki-irradiazioa iristen zaio.

- Beira zeharkatu ondoren, erradiazio horrek plaka baten gainean eragiten du, eta plaka horrek erradiazioa partzialki xurgatzen du (bere «Q» absortibitatearen arabera).

- Xaflak xurgaturiko erradiazioa transmititzen da $« \dot{m}_{f}$ jariakinaren hodietara (bere $\ll \tau$ transmisibitatearen arabera), eta jariakina berotu egiten du. 
- Xurgatutako energiaren zati bat kolektoretik galtzen da $« T_{k o l}$ tenperatura aldakorrean $\ll T_{0}$ tenperaturako girora, eroapen-, konbekzio- edo erradiazio-galerengatik. Bero-galera hori $« U_{L}$ kolektorearen transmitantzia termikoaren menpe dago.

Kolektoreen energia-erabilgarria da eguzki-erradiazioaren irabazien eta inguruneko galeren arteko aldea, hau da (Ek.(1)):

$$
\dot{Q}_{\text {erab }}=\dot{Q}_{i r a b}-\dot{Q}_{g a l}=G A \alpha \tau-\int_{A} U_{L}\left(T_{k o l}-T_{0}\right) d A
$$

Energia erabilgarri hori, era berean, $\ll T$ tenperaturan sartu eta $« T_{\text {out }}$ tenperaturan irteten den $\ll \dot{m}_{f}$ jariakinaren energia da; alegia (Ek.(2)):

$$
\dot{Q}_{u}=\dot{m}_{f} c_{p} \cdot\left(T_{s}-T_{e}\right)
$$

Kolektore baten errendimendua lan-baldintzen araberakoa da, eta erlazionatzen ditu eguzki-erradiazioa eta jariakinaren energia termikoa (Ek.(3)):

$$
\eta_{k o l}=\frac{\dot{Q}_{u}}{A G}
$$

\section{KOLEKTORE MOTAK}

Eguzki-kolektore mota anitz egon arren, gehienak bi mota hauen aldaerak dira: eguzki-kolektore laua eta huts-hodien kolektorea. Era berean, kolektorean bertan biltegiratze-sistema bat egon daiteke: zuzenean eguzkierradiazioarekin berotu daitekeena, edo diametro handiko hodiak berotzen dituena.

\subsection{Eguzki-kolektore laua}

Mota sinpleena eta gehien erabiltzen dena da, eta, aldi berean, eguzkikolektore baten bilakaera logikoena; ikus 4. irudia.

Eguzki-erradiazioa harrapatzeko, xafla ilun batean oinarritzen da. Normalean, material xurgatzaile selektibo batez estalita dago, xurgapen-gaitasuna hobetzeko, eta, aldi berean, uhin luzeko emisibitatea murrizten du (espektro infragorria), xafla xurgatzailean erradiazio-galerak murriztuz.

Plaka xurgatzailearen atzean, jariakina daramaten hodiak daude. Hodiaren materiala eroankortasun termiko handiko metal bat izaten da; batik bat, kobrea. Galera termikoak murrizteko isolatzailea jartzen da, eta atzealdean plaka islatzailea alderantzizko erradiazio-galerak murrizteko. Metalezko 
karkasak erresistentzia mekanikoa ematen dio. Aurreko aldetik, plaka xurgatzailea beira batez estaltzen da, berotegi-efektua eragiteko.

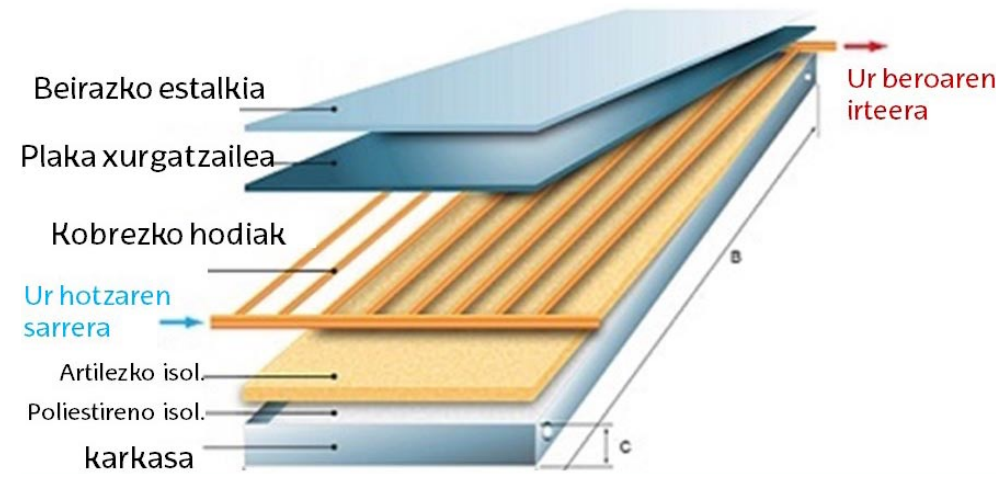

4. irudia. Eguzki-kolektore lau baten ohiko geruzak [8].

\subsection{Huts-hodien kolektorea}

Huts-hodien kolektorea modelo sinpleenaren aldaera da. Bi hodi zilindriko zentrokide ditu, eta horien artean hutsa dago. Barruko hodiaren kanpoko azalera material xurgatzaileko mintz batez estaltzen da; ikus 5. irudia. Hutsak konbekzio- zein eroapen-galerak saihesten dituenez, tenperatura altuak lortzen dira. Gainera, hutsak materialen narriadura murrizten du, eta sistemaren iraunkortasuna eta errendimendua hobetzen ditu.

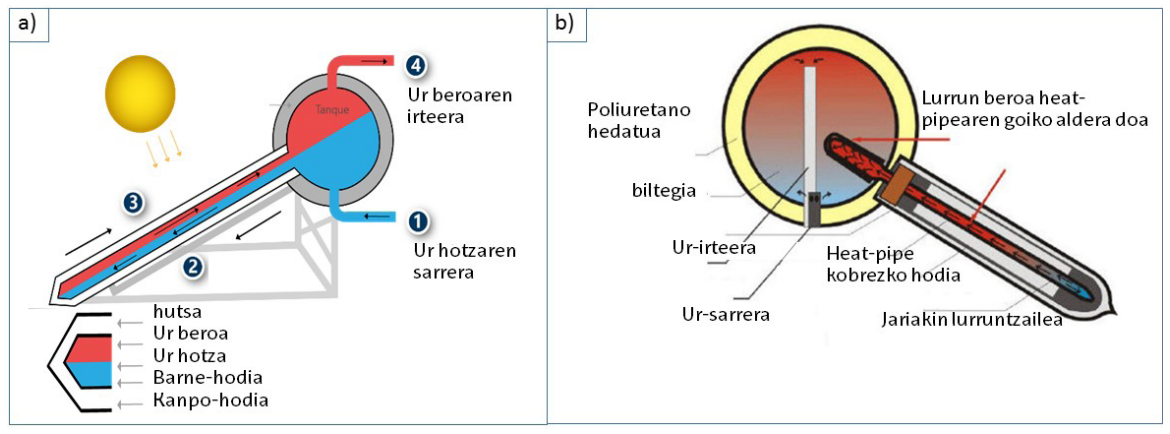

5. irudia. Huts-hodien kolektorearen funtzionamendua: a) fluxu zuzena, b) heatpipe.

Huts-hodien soluzio hobetuak daude, eta jarraian deskribatzen dira. 
Ana Picallo-Perez, Jose Maria Sala-Lizarraga, Arrate Hernandez-Arizaga

\subsubsection{Bero-hodien kolektorea (heat-pipe)}

Bero-hodiak (heat-pipeak) hodi itxiak dira, eta jariakin lurrungarri bat daukate barnean; ikus $5 \mathrm{~b}$ irudia). Eguzkitan jartzean, barruko jariakinaren zati bat lurrundu egiten da, eta goiko aldera igotzen da. Goiko aldean beroa trukatzen du berotu beharreko jariakin nagusiarekin. Beroa ematean, bero-hodiaren barnealdeko jariakina kondentsatu egiten da, eta behealdera erortzen da, non berriz lurruntzen baita eguzki-erradiazioarekin berotzean. Sistema horri esker, gain-beroketa saihesten da. Heat-pipe motak aurrerago aztertuko dira.

\subsection{Bestelako konfigurazioak}

Gaur egungo merkatuan, gehienbat bi kolektore mota horiek egon arren, badira ezagutu beharreko beste aldaera batzuk ere: ikus 6. irudia [6].

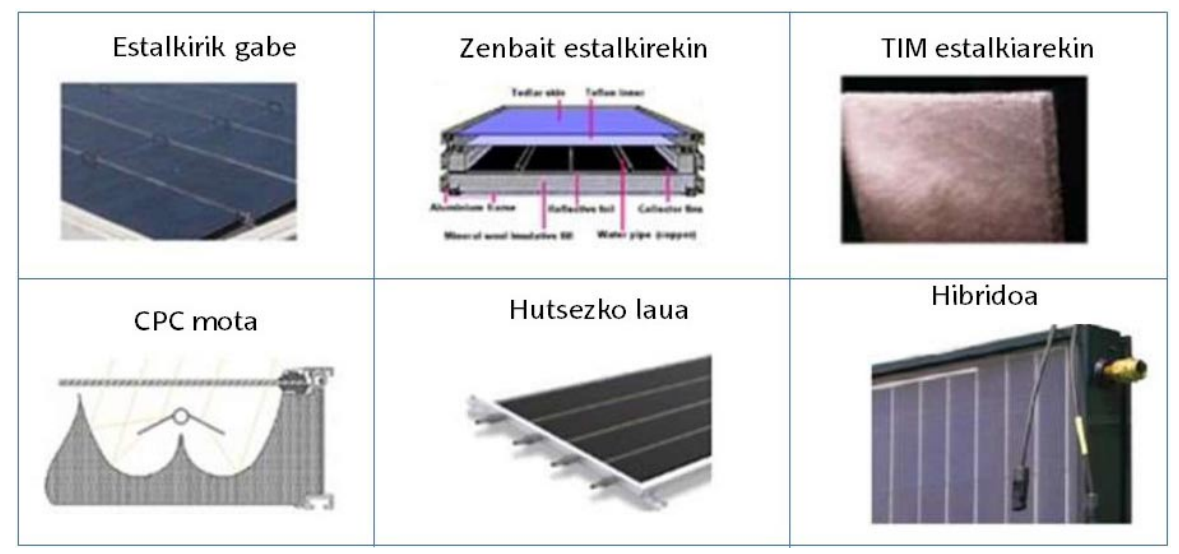

6. irudia. Beste eguzki-kolektore mota batzuk [6].

\section{KOLEKTORE LAUEN BERRIKUNTZAK}

Atal honen helburua da eguzki-kolektore lauen berrikuntzen eta garapenen joerak labur deskribatzea. Azterketa hori [9] eta [10] erreferentzietan oinarritzen da, eta, zehatza ez bada ere, teknologia-garapenaren azken hamabost urteen ikuspegi orokorra erakusten du.

Ekonomia-ikuspegia laburpen honetatik kanpo egon arren, teknologia berri interesgarriak aipatzen dira: material berriak, geometria berritzaileak, bero-hodien kolektoreen berrikuntzak, bero-transferentziako fluido berriak eta kolektore hibrido pv-termikoak. Oro har, berrikuntzen helburua da instalazioaren eraginkortasuna handitzea, zenbait estrategia eta emaitza erabi- 
liz. Gainera, kasu guztietan, ekonomikoki erakargarriak eta birziklagarriak dira, eta ingurumen-inpaktu txikia dute.

\subsection{Material berritzaileak}

Propietate erradiatiboek, hala nola emisibitateak, erreflektibitateak, absortibitateak eta transmisibitateak, balio anitz dituzte espektro elektromagnetikoaren mailaren eta norabidearen arabera. Propietate erradiatibo egokiak dituzten materialak behar bezala hautatzen badira, hobeto aprobetxa daiteke eguzki-erradiazio intzidentea.

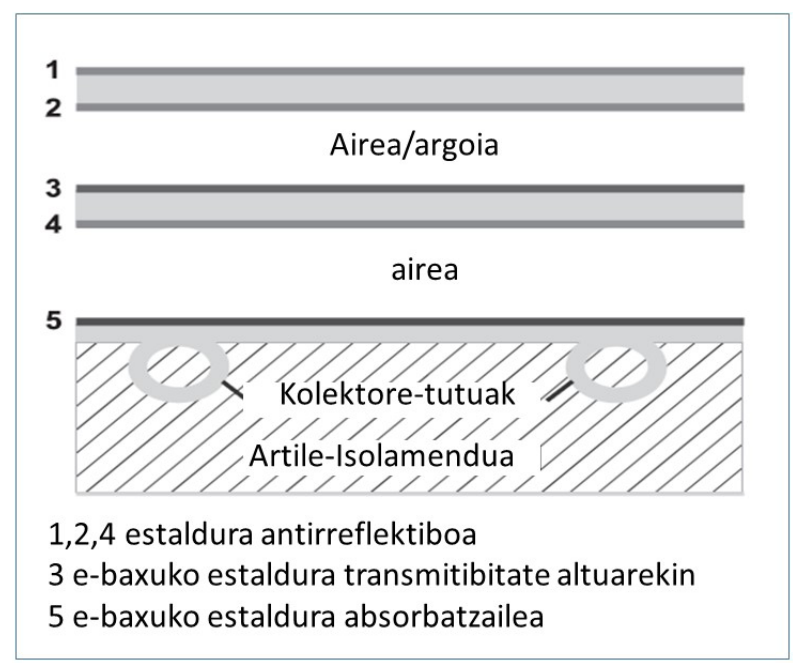

7. irudia. Eguzki-kolektorearen zeharkako atala [11].

Ehrmann-ek eta bestek [11] eroale garden oxidoen (TCO) propietate optikoak ikertu zituzten, islapenaren aurkako estaldura gisa erabiliz. Horrela, beiraren eguzki-transmisibitatea handitzeko, burdina-eduki txikiko beirak eta islapenaren aurkako estaldura gehigarriak erabili zituzten; ikus 7. irudia. Geruza selektibo horien transmisibitatea $\% 85$ ingurukoa zen, beste geruza konbentzional batzuk baino altuagoa (\% 71). Estalkiaren gainazalean erreflektibitate txikiko estaldura erabiltzean, eguzki-kolektore lau horren errendimendua handitu egin zen (\% 77 inguru), ohiko kolektorearekin alderatuta.

Bhowmi-ek eta Amin-ek [12] sistema konbinatu bat ikertu zuten (eguzki-kolektore laua eta alboetan islatzailea konbinatuz); ikus 8. irudia. Ohiko kolektorearekin alderatuta, eraginkortasun termikoa \% 10 hobetu zen. 
Ana Picallo-Perez, Jose Maria Sala-Lizarraga, Arrate Hernandez-Arizaga

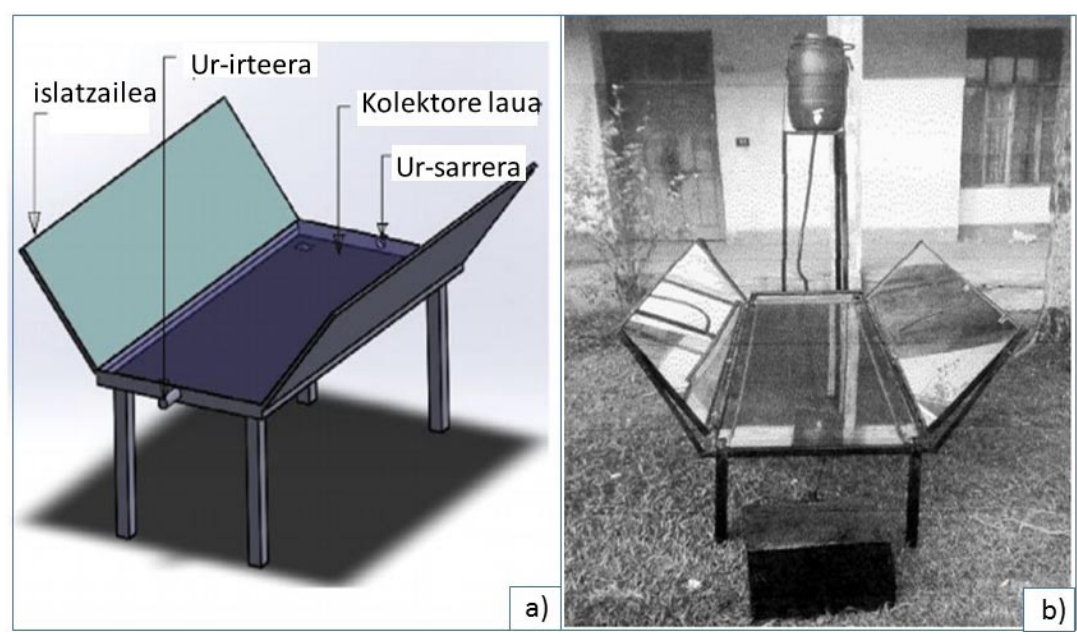

8. irudia. (a) Kolektore lauaren eskema islatzailearekin; (b) sistemaren argazkia [12].

Cindrellak [13] eguzki-estaldura selektiboak aztertu zituen zenbait propietate optikoren balioekin; ikus 1. taula. Lortutako emaitzen artean CoCd-BA estaldura nabarmentzen da, emisibitate txikiko (\% 6) eta absorbitate handiko (\% 96) konbinazioaz errendimendu handia baitu (\% 91).

1. taula. Aztertutako kolektoreen propietate optikoak eta estaldurak [13]

\begin{tabular}{ccccc}
\hline Mota & Estaldura & $\alpha$ absortibitatea & $\varepsilon$ emisibidadea & $\eta$ etekina $60{ }^{\circ} \mathrm{C}-\tan$ \\
\hline 1 & Co-Cd & 0,93 & 0,07 & 0,88 \\
2 & Co-Cd-BT & 0,96 & 0,12 & 0,87 \\
3 & Co-Cd-BA & 0,96 & 0,06 & 0,91 \\
4 & Ni-Cd & 0,94 & 0,10 & 0,86 \\
5 & Ni-Cd-BT & 0,95 & 0,17 & 0,82 \\
6 & Ni-Cd-BA & 0,91 & 0,11 & 0,83 \\
\hline
\end{tabular}

\subsection{Geometria berritzaileak}

Geometria berriak, batez ere, aire-eguzki bidezko kolektoreak hobetzeko aztertzen dira; alegia, berotzen den jariakina airea da, eta etxebizitza girotzeko balio du.

Fernández-ek eta bestek [14] «kanal»en kontzeptua garatu zuten, kanal parabolikoen karkasa islatzaile batean oinarrituz. Horiek hodi-kolektore beltzez eta beiraz osatzen dira; ikus 9. irudia. Prototipoa egin ondoren, esperimentalki zehaztu zuten \% 41-57 arteko errendimendu termikoa. 


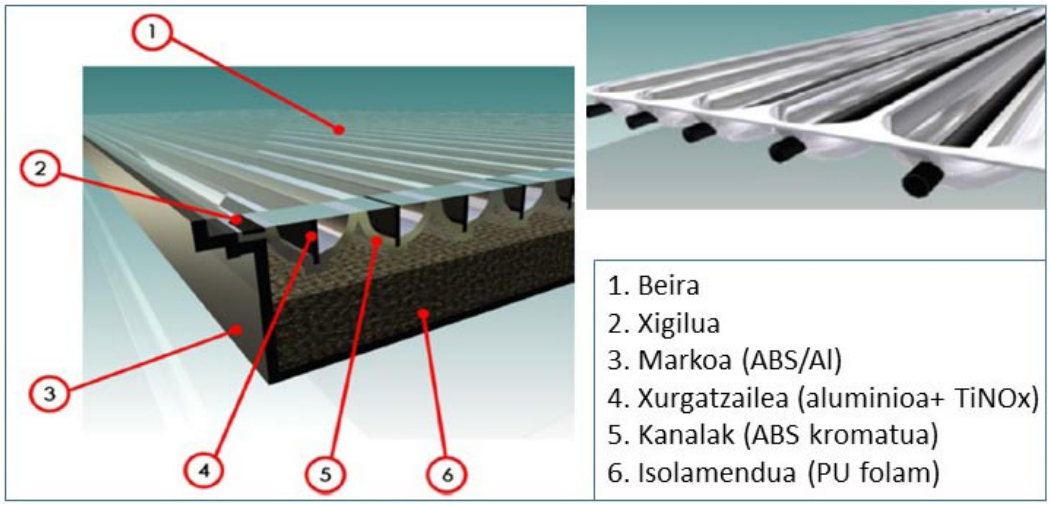

9. irudia. Kolektorearen osaera [14].

Youcef-Ali-k [15] plaka angeluzuzeneko hegats-kolektoreak aztertu zituen, eta errendimendu termikoa optimizatzeko azterketa teorikoa egin zuten, hainbat beira alderatuz. Gainera, saiakuntza esperimentala egin zuten prototipo moldagarri batekin; horrela, hainbat hegal laukizuzen diseinatu zituzten; ikus 10 . irudia, eta 2,5, 5,0, 10,0 eta 20,0 cm-ko luzerekin, hurrenez hurren. Ondorioztatu zuten hegalaren luzera txikitu ahala errendimendu termikoa handitzen zela. Gainera, beira hirukoitzak kolektore termiko lauen errendimendua handitu zuen $(\% 39, \%$ 67, \% 68, \% 62 eta \% 59 balioez $2,5 \mathrm{~cm}, 5 \mathrm{~cm}, 10 \mathrm{~cm}$ eta $20 \mathrm{~cm}$-ko hegalekin).

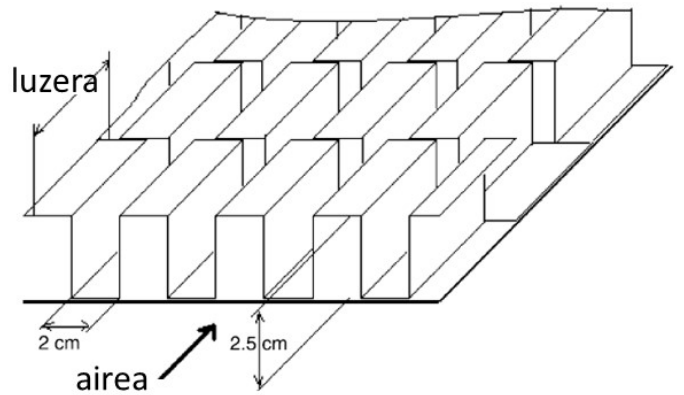

10. irudia. Xurgatzaileko hegalen konfigurazioa [15].

El-Sawi-ek eta bestek [16] Chevron ${ }^{1}$ patroi baten metalezko xafla tolestuak aplikatu zituzten aireko eguzki-kolektore lauetan. Autore horiek eredu teoriko bat proposatu zuten plaka laua, chevron patroia eta $\mathrm{v}$ motako xur-

${ }^{1}$ Zerra-horzdun konfigurazio geometrikoa da. Ziri- edo bizkarrezur-patroi ere esaten zaio. 
gatzaile patroiak alderatzeko; ikus 11. irudia. Emaitza teorikoen arabera, chevron patroiaren errendimendua $\% 10$ eta $\% 20$ handitu zen, v motarekin eta plaka lauarekin alderatuta.

\section{IKERTUTAKO KONFIGURAZIOAK}

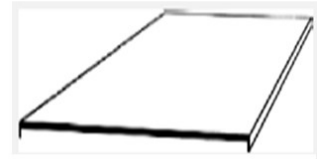

Laua

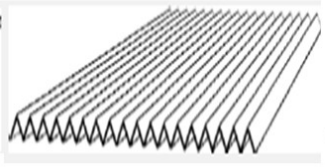

V-en ildaskatua

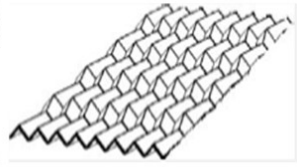

Chevron patroia

11. irudia. Analizaturiko modeloak [16].

Ozgen-ek eta bestek [17] aluminio latadun fluxu bikoitzeko eguzki-kolektoreak esperimentalki ikertu zituzten errendimendu termikoa kalkulatzeko. Aluminiozko latak plaka xurgatzailean sartzean bero-transferentziaren eremua handitu egiten zen, eta aire-fluxua bermatzen zen plaka xurgatzaileen gainean eta azpian, latek turbulentziak sortzen zituztelako eta kolektorean eremu hilak murrizten zirelako. Plaka xurgatzailean sigi-sagan jarritako laten kolektoreak \% 72ko gehieneko errendimendua zuen $0,05 \mathrm{~kg} / \mathrm{s}-\mathrm{ko}$ emarirako, ikus 13. irudia.

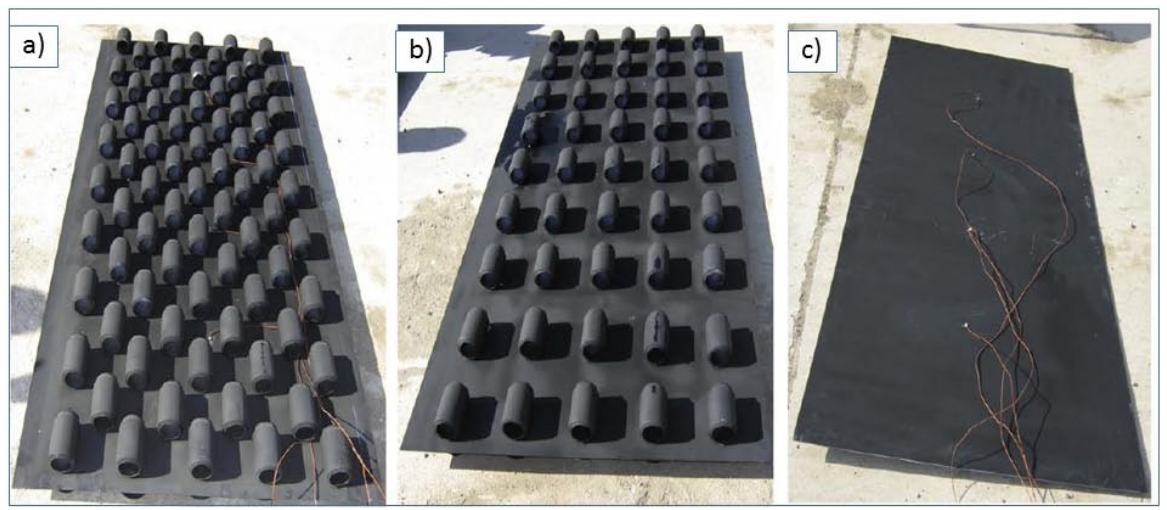

12. irudia. Plater xurgatzaile motak eta laten posizioak [17]

Peng-ek eta bestek [18] aireko eguzki-kolektore berri baten errendimendua ebaluatu zuten, orratz motako hegalen xurgatzailea integratuz; ikus 12. irudia. Egileek modelo original bat garatu zuten, kostu txikikoa, iraunkortasun handikoa, errendimendu termiko handikoa (bero-transferentzia koefiziente handia zuelako) eta malgutasun handikoa. 


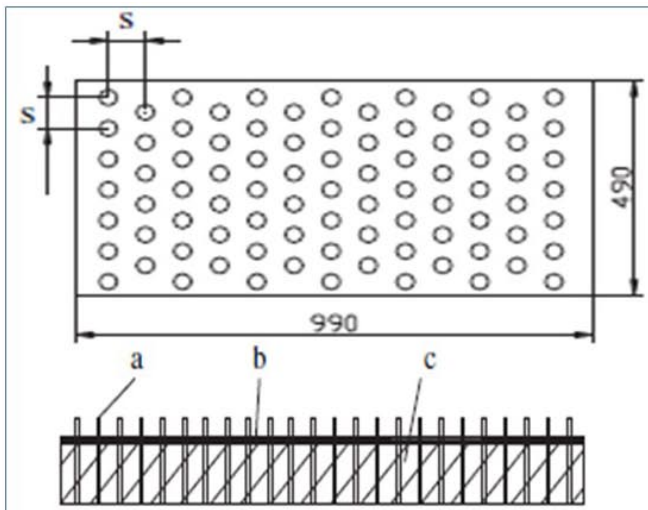

a) Orratzen hegats metalikoak

b) Xurgatzailea

a)

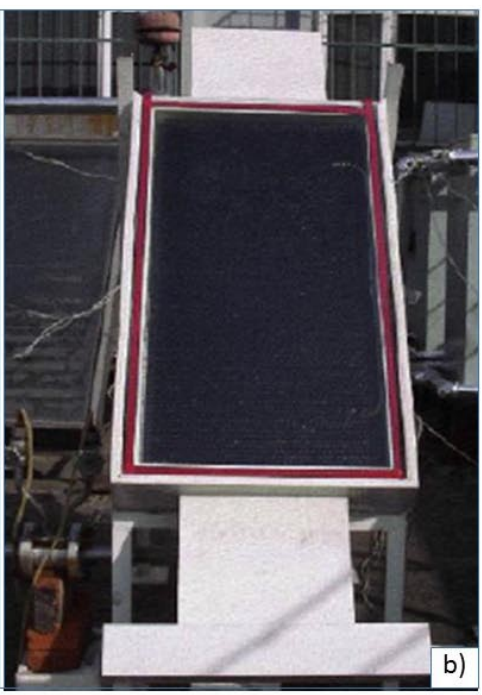

13. irudia. Orratzen hegalen kolektoreak. a) Konfigurazioa eta b) Prototipoa [18]

Abene-ek eta bestek [19] eguzki-kolektore berri bat proposatu zuten oztopo-elementurekin. Eguzki-kolektorea oztopoekin (\% 50eko errendimendua) eta oztoporik gabe (\% 25eko errendimendua) alderatu zuten; ikus 14. irudia.

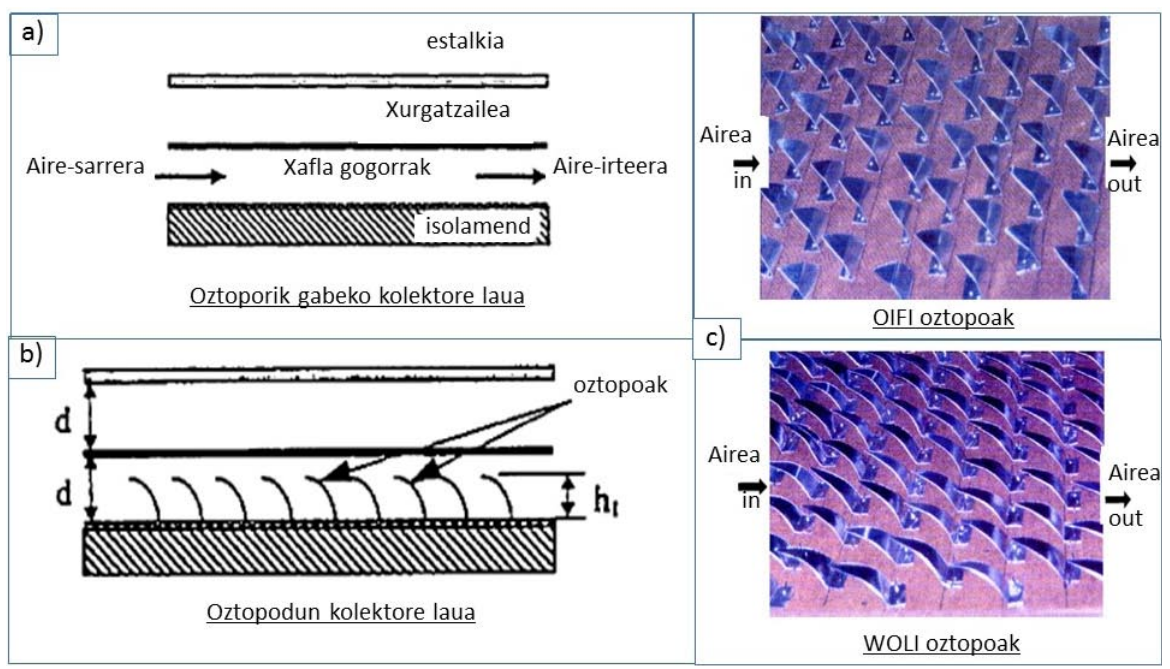

14. irudia. Kolektore lauaren konfigurazioa, (a) oztopoekin, (b) oztoporik gabe eta (c) oztopo batzuekin [19]. 
Ana Picallo-Perez, Jose Maria Sala-Lizarraga, Arrate Hernandez-Arizaga

Verma-ek eta bestek [20], eguzki-kolektore bat ikertu zuten hodi kiribilekin, bere errendimendu termikoa kalkulatzeko. Egileek ikusi zuten hodi kiribilek kolektore arruntek baino hobeto funtzionatzen zutela barnealdeko lan-baldintzetan; 15. irudian, diseinu berritzailearen eskema.

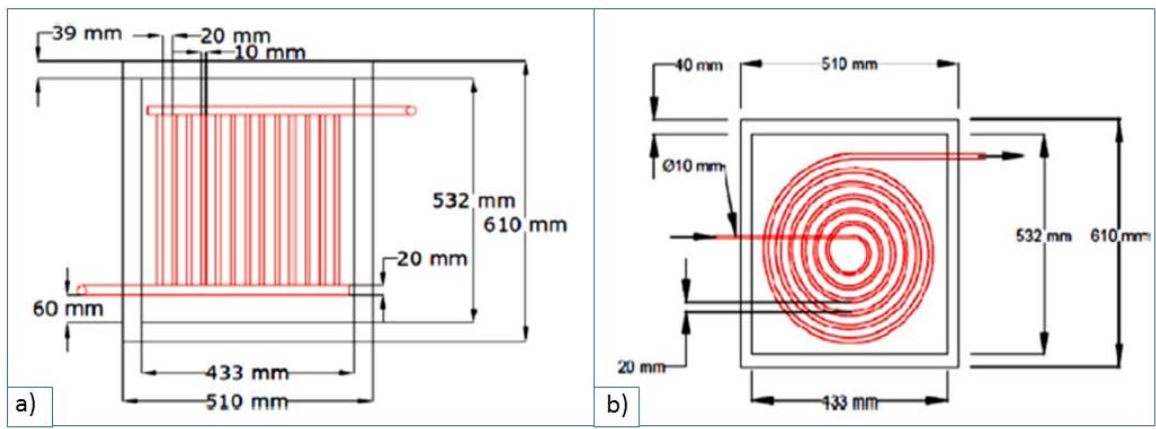

15. irudia. (a) Ohiko eguzki-kolektore planoaren eskema, (b) hodi kiribila [20].

\subsection{Bero-hodien kolektore berritzaileak (heat-pipe)}

Azad-ek [21] eguzki-kolektore berritzaile bat diseinatu eta eraiki zuen: kobrezko hodi batek inguratzen zuen bero-hodia eta bere errendimendua aztertu zituen; ikus 16. irudia.

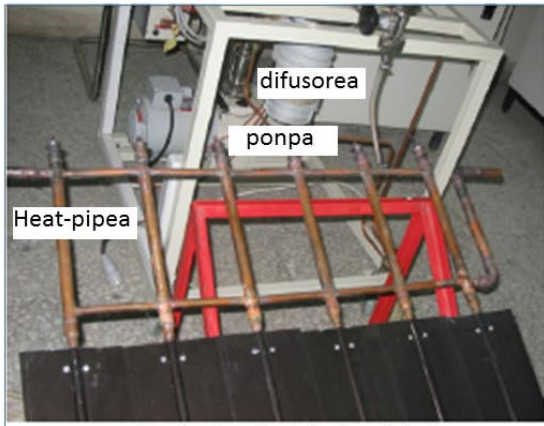

Heat-pipea betetzeko plataforma

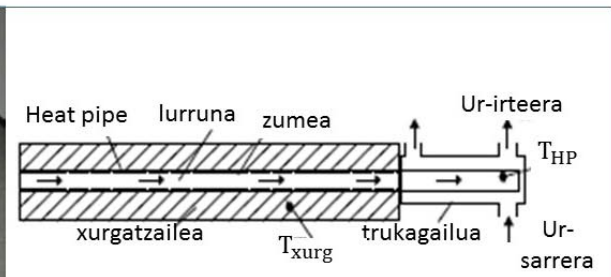

Hipe-pipe indibiduala trukagailuarekin

16. irudia. Bero-hodiaren konfigurazioa kobrezko hodian [21].

Rassamakin-ek eta bestek [22] bero-hodien kolektore bat ikertu zuten, soldadurarik gabe integratzeko asmoz. Kolektoreak estrusio bidez zigilatutako hegal bat eta aluminiozko hodi bat zituen, erresistentzia termiko minimoa bermatzeko; ikus 17. irudia. 


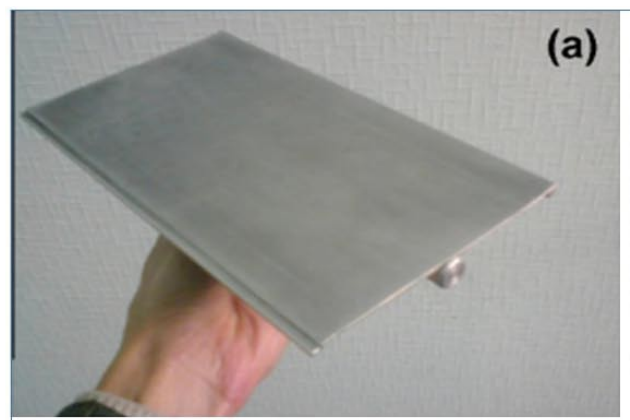

Zati baten kanpoko bista

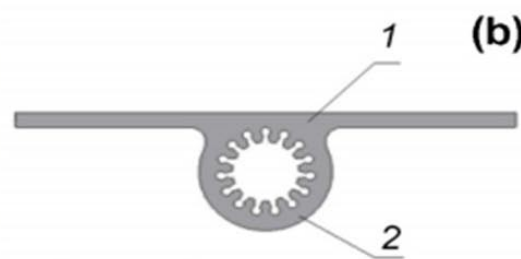

1. xurgatzailea

2. Heat-pipe ildaskatua

17. irudia. Hegatsen eta aluminiozko tutuaren bero-hodia [22].

Deng-ek eta bestek [23] mikro-kanalen bero-hodi baten errendimendua aztertu zuten: aluminiozko plaka mehe bat zen mikro-kanal motako bero-hodi independenteekin (micro-channel Heat pipe array (MHPA-FPC)); ikus 18. irudia.

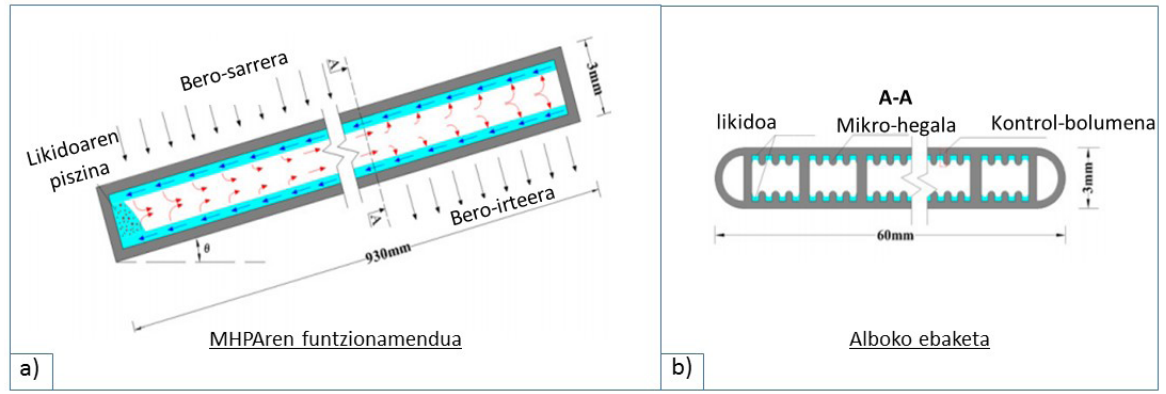

18. irudia. MHPA-FPCaren (a) profila (b) zeharkako irudia [23].

Rittidech-ek eta bestek [24] mutur itxiko bero-hodi oszilatzaile baten errendimendua ikertu zuen. Bira askotan tolestutako hodi kapilar luze bat zen (Solar Collector by Closed-End Oscillating Heat Pipe (CEOHP)); ikus 19. irudia. Laneko jariakinaren pultsazioak lurrungailutik kondentsadorerako bero-transferitzea bermatzen zuen.

Bero-hodien aplikazioak kolektore lauen aplikazioak baino ugariagoak dira; izan ere, tenperatura altuak lor daitezke, eta beroa transmititzeko hainbat jariakin erabil daitezke. Hala ere, kontu handiz diseinatu eta fabrikatu behar dira lurrunketa/kondentsazio-mekanismoak, geometriaren eta dimentsioen menpe baitaude. 
Ana Picallo-Perez, Jose Maria Sala-Lizarraga, Arrate Hernandez-Arizaga

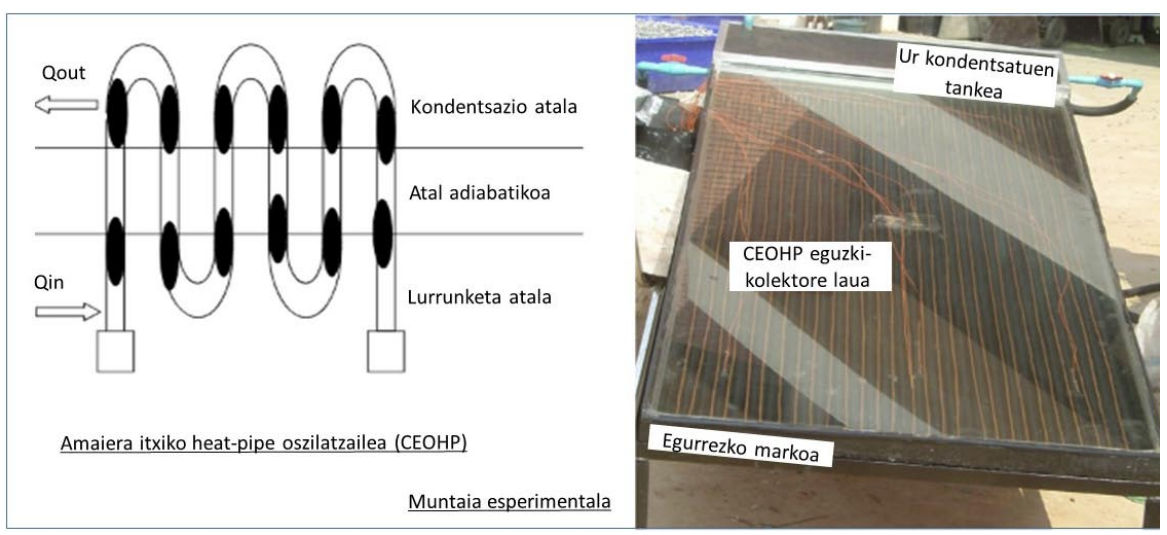

19. irudia. CEOHP bero-hodi oszilatzailearen konfigurazioa [24].

\subsection{Bero-eramaile jariakin berritzaileak}

Ura edo ur-etilenglikol nahasketa dira, oro har, eguzki-kolektoreen jariakinak. Horien eroankortasun termikoa faktore mugatzailea denez, jariakin bero-eramaile berritzaileak proposatu dira, errendimendua hobetzeko.

Fluido berri horiek nahasketa batean oinarritzen dira: metalen edo metal-oxidoen nanopartikula solidoak $(<100 \mathrm{~nm})$ ohiko jariakinekin nahasten dira (ura, etilenglikola edo olioa); ikus 20. irudia. Nahaste horiei nanofluido deritze, Choik-ek batailatua [25].

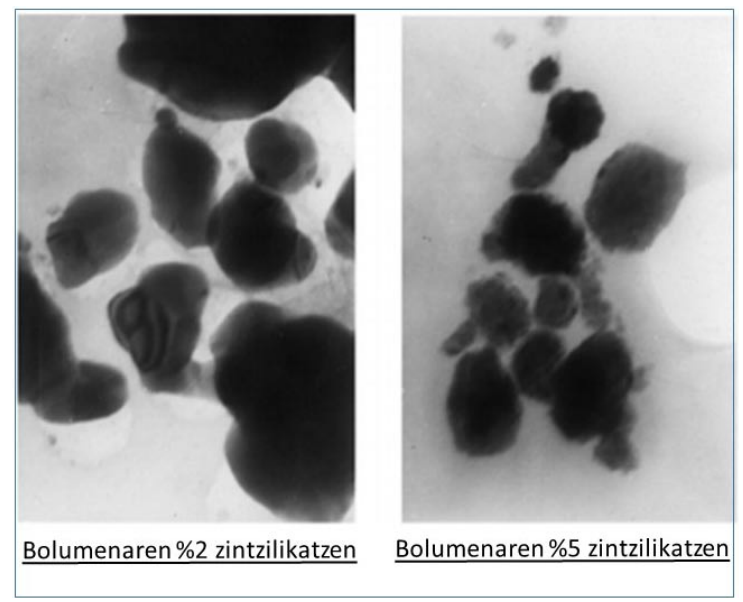

20. irudia. NanoCu partikulen TEM mikroargazkiak (100.000 eskala-denborak) [25]. 
Nanopartikulek eroankortasun termikoa eta bero-transferentziaren koefizientea handitzen dutenez, kolektoreen errendimendua hobetzen dute. Nanofluidoak partikula mikrometrikoekin edo milimetrikoekin egindako esekidurak baino egonkorragoak dira, baina beharrezkoa da ondo diseinatzea eta osagai hidraulikoak behar bezala aukeratzea, sedimentazioa saihesteko.

Nanofluido-analisiaren adibide gisa, Rahman-ek eta bestek [26] simulazio-eredu teoriko bat egin zuten, eguzki-kolektore baten $\mathrm{CNT} / \mathrm{H}_{2} \mathrm{O}$ nanofluidoaren efektua ikertzeko. Errendimendu teorikoaren emaitzek erakutsi zuten bi faktore garrantzitsu zeudela: bolumen-solidoaren frakzioa $(\delta)$ eta eguzki-kolektorearen inklinazio-angelua $(\Phi) ; 21$. irudian agertzen da adibide bat.

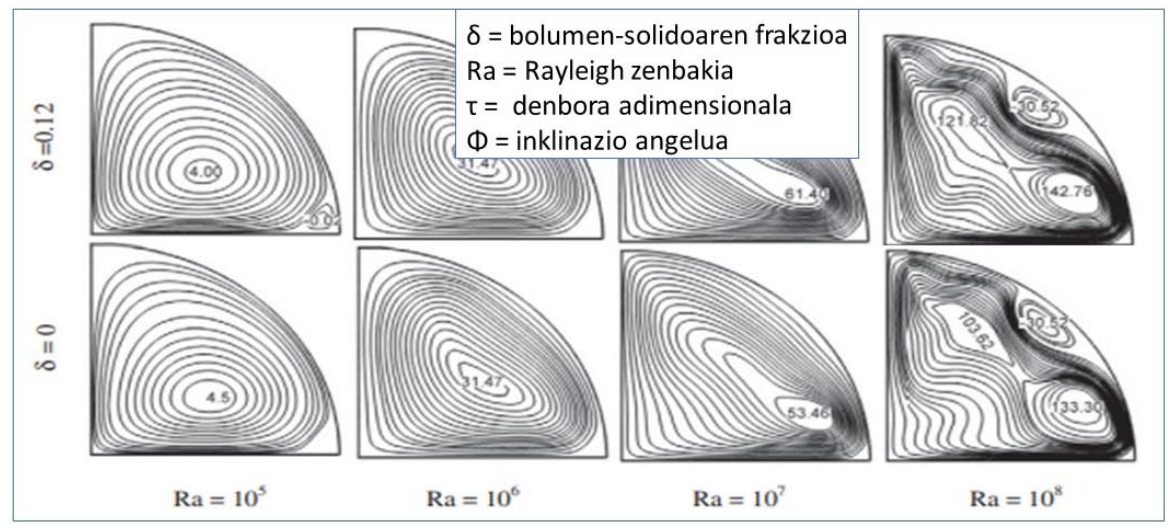

21. irudia. Bolumen solidoaren frakzioa korronte-lerroetan, Ra balioen arabera eta $\Phi=30^{\circ}, \tau=0,1[26]$.

\subsection{Eguzki-kolektore hibridoak: PV-termikoak}

Udaran, eguzki-erradiazioa altua denean, sistema fotovoltaikoek gaizki funtzionatzen dute, modulu fotovoltaikoen errendimendua alderantzizko proportzionala delako funtzionamenduaren tenperaturarekiko. Eguzki-kolektore termiko lauek, aldiz, UBS edo aire girotua sortzen dute. Beraz, bi kolektore motak konbina daitezke, fotovoltaikoak (PV) eta termikoak, horrela modulu fotovoltaikoaren tenperatura murrizten da, eta energia termikoa aire bero edo UBS moduan lortzen da. Sistema horiek eguzki sistema hibridoak dira (PVT) [27], eta tenperatura baxuko aplikazioetan erabiltzen dira [28].

Funtsean, PVT kolektore bat eroankortasun handiko metalezko plaka fin bat da, eta horren gainean ijezketa bidezko PV zelulak daude, non eguzki-erradiazioa elektrizitate bihurtzen baita; ikus 22. irudia. Aldi berean, 
jariakin bat, normalean airea edo ura, plaka xurgatzailetik igarotzen da beroa PV zeluletatik erauziz, haren tenperatura jaitsiz eta, ondorioz, errendimendu elektrikoa handituz. Bero hori hainbat aplikazioetan erabiltzen da [29].

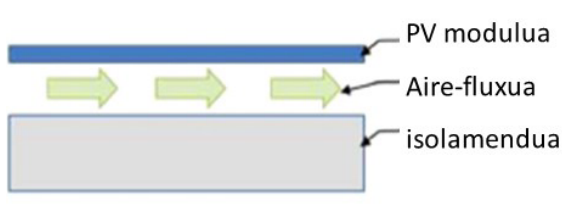

Beirarikgabeko $\mathrm{PV} / \mathrm{T}$ modulua

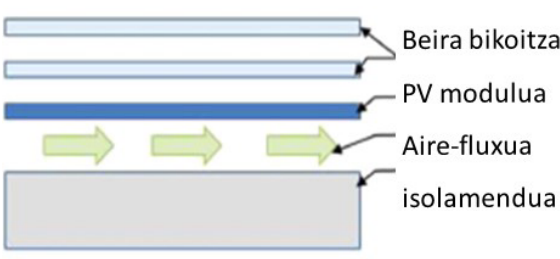

Beira bikoitzeko PV/T modulua

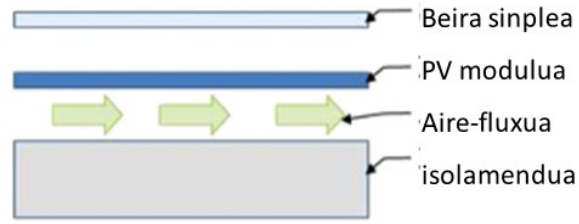

Beira sinpleko PV/T modulua

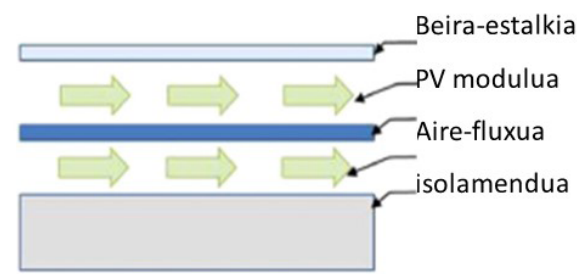

Pausu bikoitzeko PV/T modulua

22. irudia. PV/T moduluen zeharkako sekzioak [30]

PVT kolektoreen teknologia nahiko berria denez, diseinua eta merkatu-potentziala ikerketa fasean dago. Horregatik, kolektore-parametroen eraginaren zenbait berrikusketa interesgarri daude, hala nola Zhang-ek eta bestek [30], Moradi-k eta bestek [31], Arcuri-k eta bestek [32], non fluido mota, masa-emaria, estalki kopurua, eta abar aztertzen baitira; Ikus 23. irudia eta 24. irudia. Beraz, teknologia hau oso oparoa da.
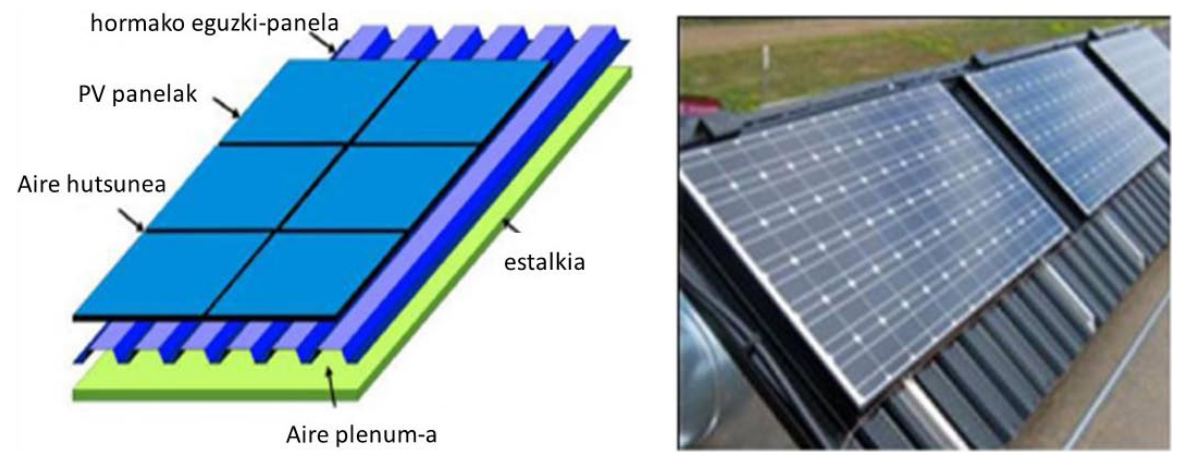

23. irudia. PVT aire-eguzki bidezko produktua; Conserval Engineering. 


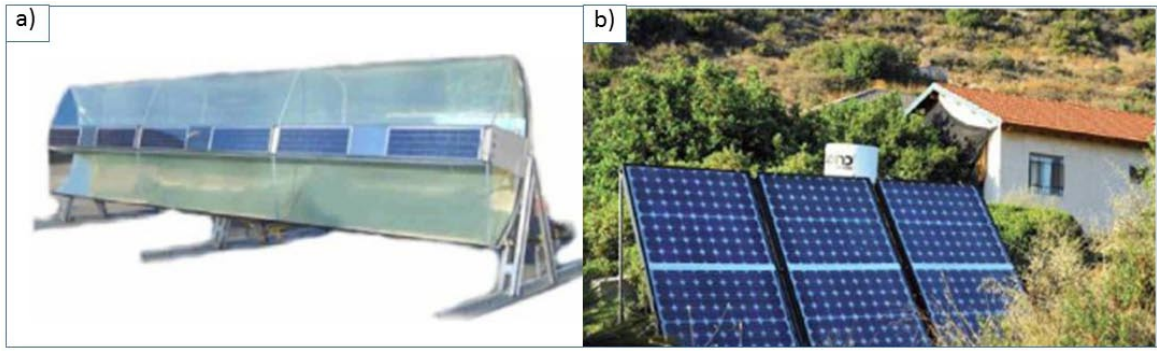

24. irudia. (a) Menova Energyren Power-spar, (b) Millennium Electricren Multi Solar PV/T sistema.

\section{EGUZKI-INTEGRAZIOA ELEMENTU ARKITEKTONIKOETAN}

Eraikinak jada ez dira eguzki-sistema pasiboekin eta aktiboekin soilik diseinatzen; hala nola leihoekin eta eguzki-espazioekin (pasiboak), edo, eguzki-kolektoreekin (aktiboak). Izan ere, pasiboaren eta aktiboaren bereizketak jada ez du zentzu handirik, eraikin berriek bi motatako teknologiak konbinatzen baitituzte. Energetikoki eraginkorrak izan daitezke, eguzki-energiaz berotu edota hozten badira eta sistema fotovoltaikoz elikatzen badira; laburbilduz, «eguzki-eraikinak» dira [33].
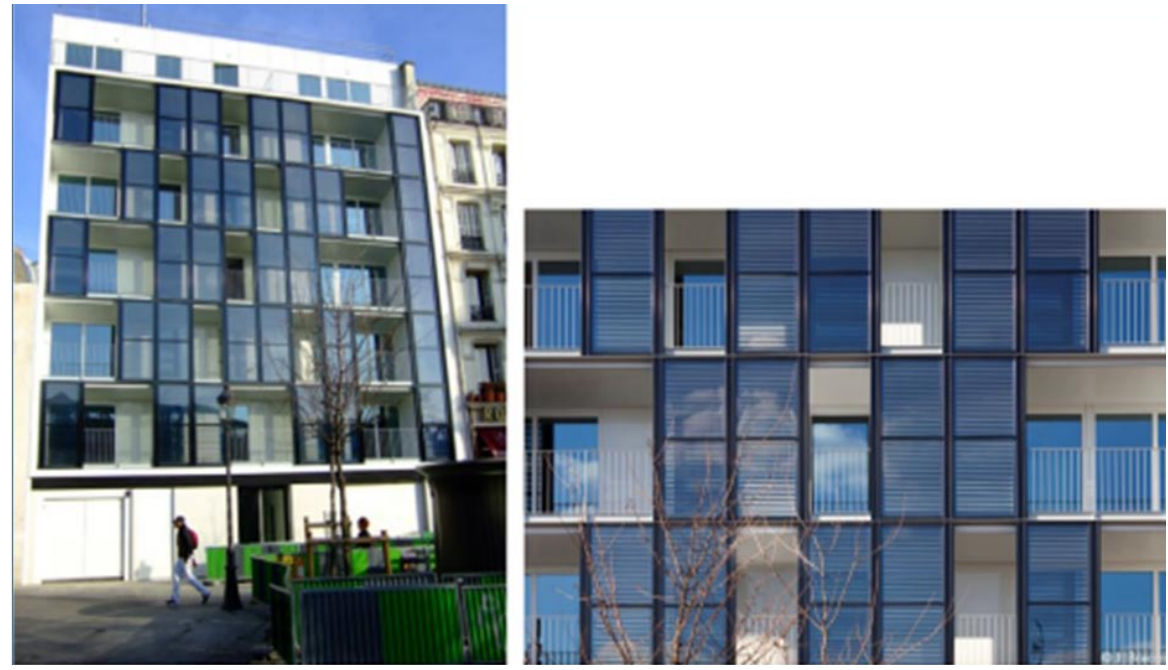

25. irudia. Fatxadan eguzki-kolektoreak dituen isolamendu erdi-garden termiko baten argazkiak, Paris RobinSun. 
Oro har, eraikin bat desinatzean, lehenik eta behin, energia-kontsumoa murrizteko teknologiak aztertzen dira; gero, eguzki-teknologia pasiboak integratzen dira; eta, ondoren, eguzki-teknologia aktiboak eta teknologia fotovoltaikoak. Hala ere, energia-kontsumoa murrizteko kasu gehienetan teknologia guztiak erabili behar dira. Beraz, proiektuen arrakasta-gakoa da diziplina anitzeko taldeak batzea; alegia, ikuspegi «holistikoa» izatea; ikus 25. irudia.

Adibide bat Plan-les-Ouates-eko etxebizitzak dira, Genevatik mendebaldera [33]. Proiektu honetan, hegoaldera begira dagoen estalkiak eguzkikolektoreak ditu. Estalkiek inklinazio handia dute, eta proiektuaren arkitektura hobetzen dute, espazioak berotuz eta UBS ekoitziz.

Azken urteotan, ikerketa asko gauzatu dira eguzki-elementu modularrak eta eraikuntza-egitura integralak garatzeko eta aplikatzeko. 1.000 patente eta industria-produktu inguru daude eguzki-sistema termikoetan, fotovoltaikoetan eta eguzki-sistema hibridoetan oinarrituz; ikus adibidea 26. irudian.

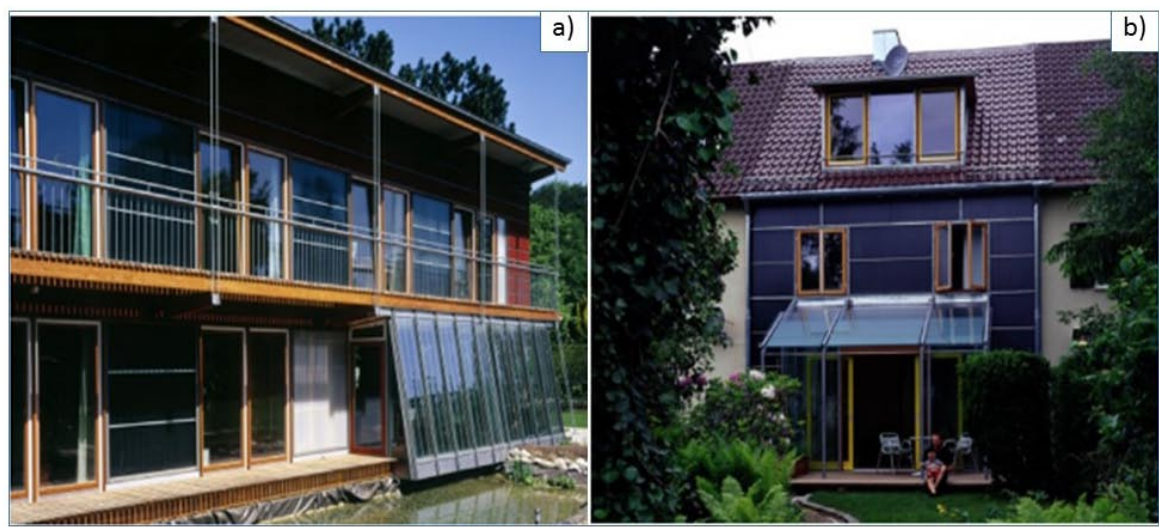

26. irudia. (a) Munichen eraikina Lichtblau Architektenen BISTarekin, (b) BIST duen terraza.

\subsection{Eguzki-kolektore integratuak}

Atal honetan, eraikinetan integratutako eguzki-kolektoreen aldaerak deskribatzen dira, zeintzuek ingurumen-inpaktuaren erregulazio zorrotzak eta estetika-mugak zorrotz betetzen baitituzte [34].

Hazami-ek eta bestek [35] eguzki-kolektore baten errendimendua aztertu zuten, biltegiratzeko ahalmenarekin, eta geruza hauek zituen: espazio huts bat; geruza selektibo bat; hormigoizko geruza; eta isolamendu termikoa; ikus 27. irudia. Datu esperimentalen emaitzek, biltegiratze- eta deskarga-etapetan, hau baieztatu zuten: sistema integratuak, merkea eta maneiagarria izateaz gain, egunez energia termikoa biltegiratzen zuen 
$\left(96,4 \mathrm{kWh} / \mathrm{m}^{3}\right)$ gauez erabiltzeko; gainera, $50^{\circ} \mathrm{C}$-ko tenperaturara irits zitekeen $980 \mathrm{~W} / \mathrm{m}^{2}$-ko irradiantziarekin; eta $1,5 \mathrm{~kW}$-eko potentzia lortu, $5 \mathrm{~m}^{2}$-ko azalerarekin eta \% 30eko errendimenduarekin.

\section{Geruza selektiboa}

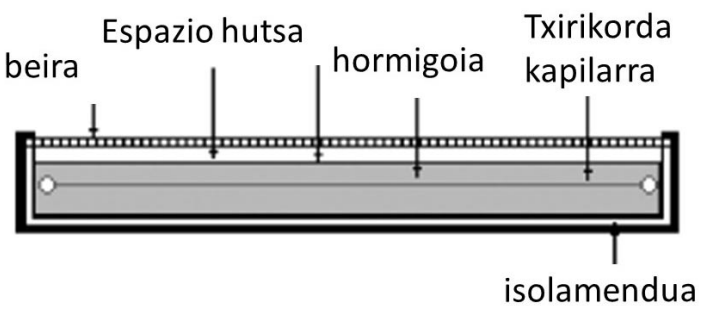

27. irudia. Biltegiratzeko eguzki-kolektorearen diagrama [35].

Motte-ek eta bestek [36] eguzki-kolektore termiko integratu berri bat diseinatu zuten, simulazio-eredu teoriko bat garatuz. Kolektorearen barruan hodi «beroak» eta «hotzak» zeuden elkarrekin; ikus 28. irudia. Horrela, ondo integratzen zen hegoaldeko eta iparraldeko hormetan. Kolektore-moduluak paraleloan muntatuta zeuden, eta estetikoki ikusezinak dira; $\%$ 60ko errendimendua lortu zen.

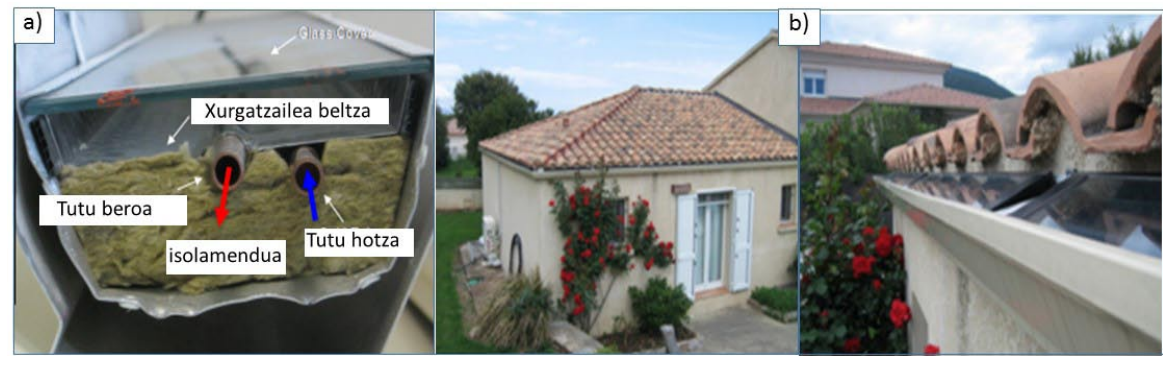

28. irudia. (a) Eguzki-modulu termikoaren egitura, (b) eguzki-kanala $\mathrm{H}_{2} \mathrm{SS}^{\circledR}[36]$.

Matuska-ek eta bestek [37] eraikinaren fatxadan eguzki-kolektore bat integratu zuten. Fatxada horretan daude kristalak, aire-ganbera bat, xurgatzailea, isolamendu-geruza eta, azkenik, horma. Konfigurazio horren berezitasuna da eguzki-kolektorea zuzenean eraikineko hormen isolamenduaren gainean dagoela. Gainera, eraikina baldintza atmosferikoetatik babesten du, estetika altua du (eraikinaren hormetan egurrezko marko batekin muntatzen delako), eta propietate termikoak hobetzen ditu; ikus 29. irudia. Simulazioa- 
ren emaitzek agerian utzi zuten fatxadaren eguzki-azalera \% 30 handitu zitekeela $45^{\circ}$-ra inklinatutako ohiko eguzki-sistema termikoekin alderatuz.

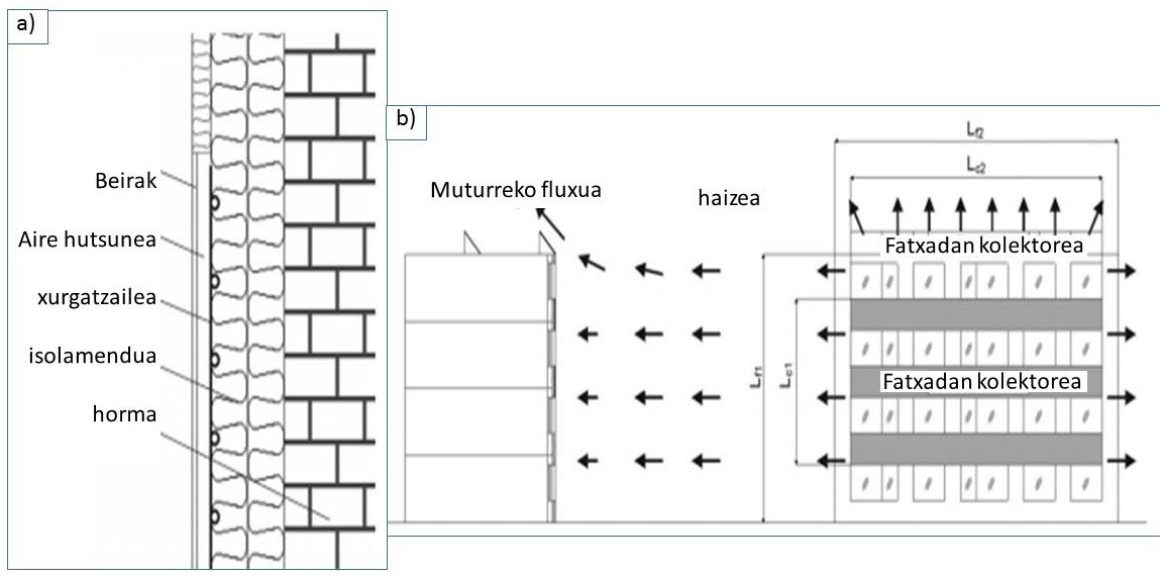

29. irudia. (a) Eguzki-kolektorea fatxadan, (b) haize-e,aroa eta egizlo-kolektoreak eraikinean [37].

Juanicok [38] estalkian integratutako ur-kolektore bat aurkeztu zuen. Korrosio atmosferikoaren aurkako material higagaitzez osatzen zen; estalkiaren eremu txiki bat behar du, eta eraikuntza-denbora murritza da. Sistema interesgarria da etxea berotzeko, neguan eguzkiaren irradiazioa hartzen baitu. Bestalde, udako egun batean, ur-xafla bat sortzen da kolektorearen beiran, eta horrek hozkuntza ebaporatiboa eragiten du. Gainera, gauean ura hoztu egiten da eta goizean ponpatzen da barrualdea konbekzio natural bidez hozteko; ikus 30. irudia.

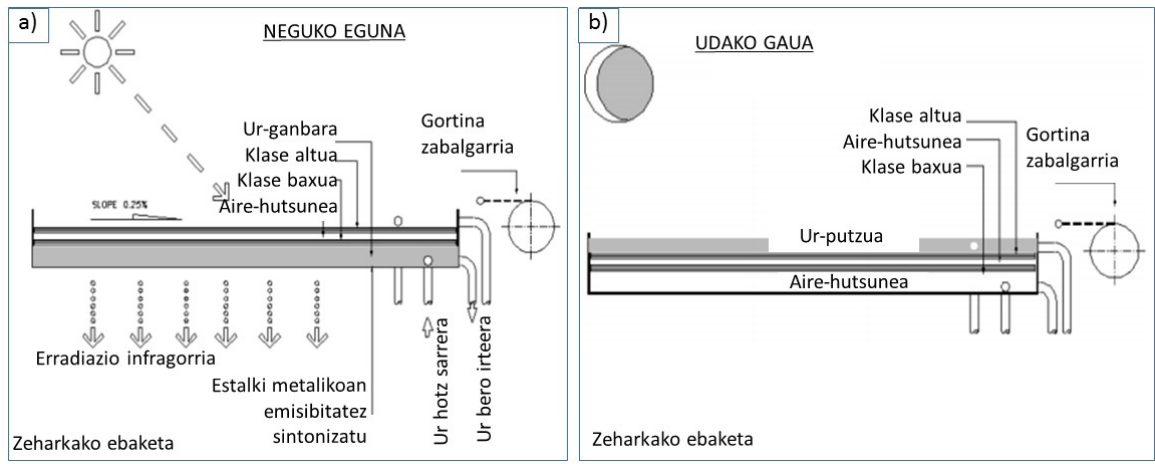

30. irudia. Kolektorearen konfigurazioaren eskema, (a) neguko eta (b) udako gau batean [38]. 
Visa-ek eta bestek [39] fatxada trapezoidalaren diseinu optimizatu bat sortu zuten, eguzki-kolektore lauekin. Fatxadan integratutako eguzki-kolektorearen irudia eta kobrezko hodiaren konfigurazioa; 31. irudian.
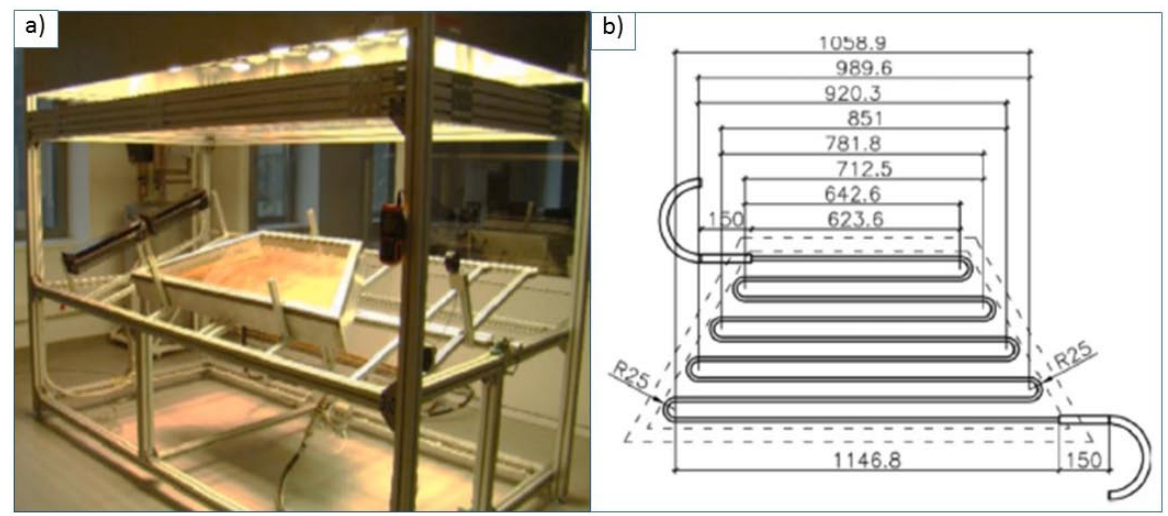

31. irudia. (a) Fatxada trapezoidala, eguzki-kolektoreekin integratua. (b) Meandro motako kobre jarraituaren konfigurazioa [39].

\section{EGUZKI-HOZTEA}

Espainiako kokapen geografikoa eta klima kontuan hartuta, leku asko hoztu behar dira udan. Hotza konpresiozko sistema mekanikoen bidez lortzen da, batez ere. Kontuan izan behar da eskaria areagotu egiten dela egunaren eguerdian eta udan. Beraz, hozkuntza-eskariak eta eguzki-energiaren eskuragarritasunak bat egiten dutenez, eguzki-energiarekin hotza lortzeko soluzioak erakargarriak dira. Hala ere, konplexuagoa da eguzki bidezko hozte-instalazio bat diseinatzea, hozkuntza-eskaria ezagutu behar delako eta oso aldakorra delako [6].

Eguzki bidezko hozte-sistemak sistema itxiak izan daitezke, xurgapenedo adsortzio-ekipoak, edo sistema irekiak, ekipo lehorgarriak (desekanteak). Teknologia garrantzitsuen egungo aurrerapena eta eguzki bidezko hozte-sistemen garapena [40] erreferentzian laburtzen da; ikus 2. taula. Halaber, erreferentzia berean aipatzen dira berotzeko eta hozteko eguzkisistemen egungo egoera, berrikuntzak eta etorkizuneko merkatuaren aukerak. 
Ana Picallo-Perez, Jose Maria Sala-Lizarraga, Arrate Hernandez-Arizaga

2. taula. Hotz eguzki-sistemen laburketa [40]

\begin{tabular}{|c|c|c|c|c|}
\hline Taldea & \multicolumn{2}{|c|}{ Makina mota } & Tenperatura & Eraginkortasuna \\
\hline \multirow{4}{*}{$\begin{array}{l}\text { Hozkokuntza- } \\
\text { rako eguzki- } \\
\text { kolektorea }\end{array}$} & \multicolumn{2}{|c|}{ Kolektore laua } & $30-80{ }^{\circ} \mathrm{C}$ & $40-80 \%$ \\
\hline & \multicolumn{2}{|c|}{ Huts-hodien kolektorea } & $30-80{ }^{\circ} \mathrm{C}$ & $60-75 \%$ \\
\hline & \multicolumn{2}{|c|}{ Parabolikoa } & $30-150^{\circ} \mathrm{C}$ & $45-75 \%$ \\
\hline & \multicolumn{2}{|c|}{$\mathrm{PV} / \mathrm{T}$} & $30-60{ }^{\circ} \mathrm{C}$ & $50-70 \%$ \\
\hline & & & Bultzada $\mathrm{T}$ & COP termikoa \\
\hline \multirow{7}{*}{$\begin{array}{l}\text { Ohiko hotz- } \\
\text { sistemak }\end{array}$} & \multirow{3}{*}{ Adsortzio makinak } & Silize gela-ura & $60-100{ }^{\circ} \mathrm{C}$ & $0.3-0.6$ \\
\hline & & Zeolitea-ura & $150-250{ }^{\circ} \mathrm{C}$ & $0.2-0.4$ \\
\hline & & Amoniakoa-CaCl${ }_{2}$ & $100-150{ }^{\circ} \mathrm{C}$ & $0.2-0.4$ \\
\hline & \multirow{4}{*}{ Xurgatze makinak } & $\begin{array}{l}\text { Egoera sinplea. } \\
\text { Amoniako-ura }\end{array}$ & $90-120^{\circ} \mathrm{C}$ & $0.4-0.6$ \\
\hline & & $\begin{array}{l}\text { Efektu sinplea } \\
\text { LiBr-ura }\end{array}$ & $80-100{ }^{\circ} \mathrm{C}$ & $0.6-0.7$ \\
\hline & & $\begin{array}{l}\text { Efektu bikoitza } \\
\text { BiBr-ura }\end{array}$ & $140-160{ }^{\circ} \mathrm{C}$ & $1.0-1.2$ \\
\hline & & $\begin{array}{l}\text { Ef. hirukoitza } \\
\text { LiBr-ura }\end{array}$ & $180-220^{\circ} \mathrm{C}$ & $1.3-1.7$ \\
\hline \multirow{5}{*}{$\begin{array}{l}\text { Garatu be- } \\
\text { rriko hotz- } \\
\text { sistemak }\end{array}$} & \multicolumn{2}{|c|}{$\begin{array}{l}\text { Adsortzio-makina, bero-berreskuratzailearekin eta si- } \\
\text { lizio gel-ur modulen masarekin }\end{array}$} & $86^{\circ} \mathrm{C}$ & 0.51 \\
\hline & \multicolumn{2}{|c|}{$\mathrm{CACL}_{2} / \mathrm{AC}$-amoniaco adsortzio-hozkailua } & $130{ }^{\circ} \mathrm{C}$ & 0.197 \\
\hline & \multicolumn{2}{|c|}{ LiBr-Efektu sinpleko/bikoitzeko ura xurgatzeko makina } & $\begin{array}{l}\text { eguzkitik: } \\
70-90^{\circ} \mathrm{C}\end{array}$ & $\begin{array}{l}\text { COP eguzki- } \\
\text { hotza: } 0.5-0.6\end{array}$ \\
\hline & \multicolumn{2}{|c|}{ LiBr-ura xurgatzeko makina, efektu aldakorrarekin } & $95-120^{\circ} \mathrm{C}$ & $0.69-1.08$ \\
\hline & \multicolumn{2}{|c|}{$\begin{array}{l}\text { Izotza xurgatzeko makina, barneko beroa hobeto be- } \\
\text { rreskuratzen duena amoniako-urarekin }\end{array}$} & $160{ }^{\circ} \mathrm{C}$ & $1.3-1.7$ \\
\hline
\end{tabular}

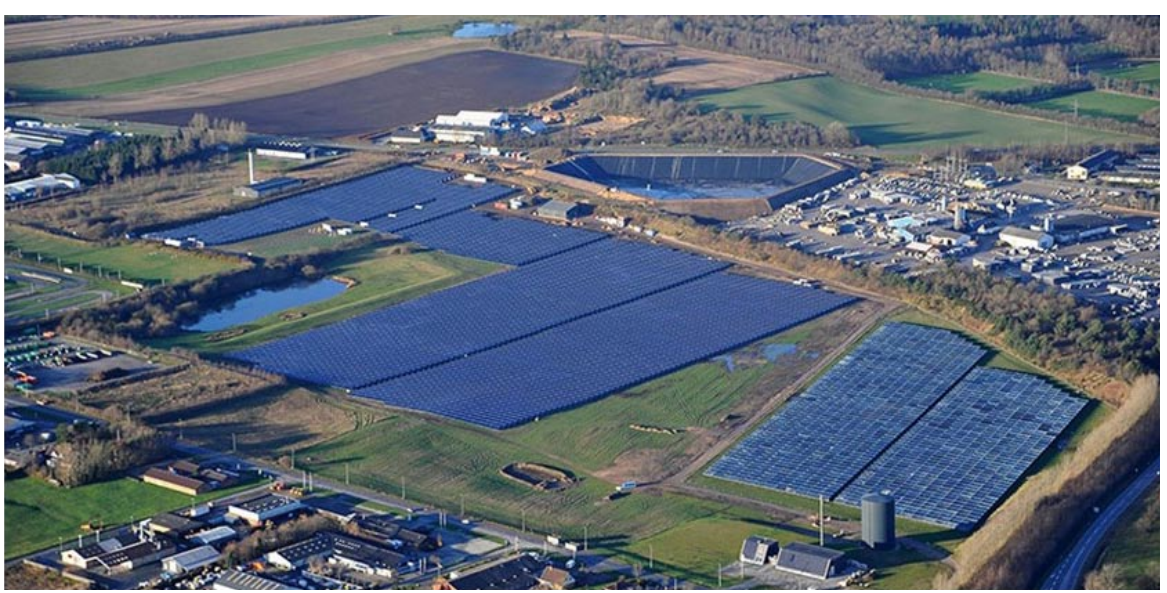

32. irudia. Eguzki sareko-berokuntza baten argazkia 


\section{KLIMATIZAZIO-SAREAK}

Erabiltzaile asko konektatzen dituen bero- edota hotz-sistema zentralizatuak daude, eta zerbitzu hauek ematen dituzte: berokuntza eta UBS (district heating, DH) eta hozketa (district heating and cooling, DHC) [29]; ikus 33. irudia eta 34. irudia. Hiri-klimatizazioko sistema gisa ere ezagutzen dira, eta, erabiltzaile asko hornitzen dituztenez, eskaera uniformeagoa dute; horri esker, ekipo sortzaileek etengabe funtzionatzen dute.

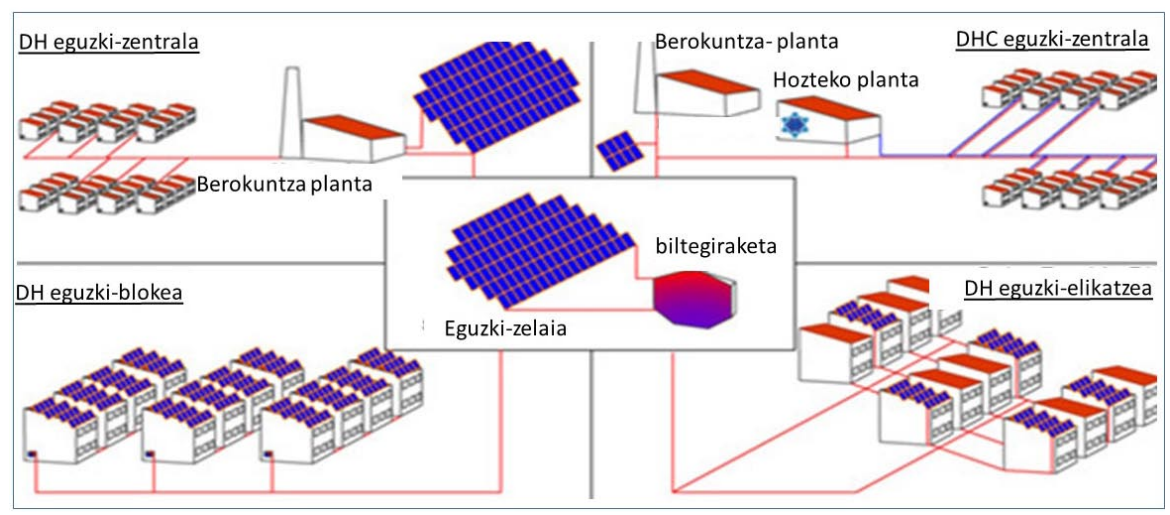

33. irudia. Eguzki-sareko berokuntza baten eskema.

Energia- eta ingurumen-ikuspegitik, klimatizazio-sareak oso alternatiba eraginkorra dira lehen-mailako energia-kontsumoa eta emisioak murrizteko, batez ere baliabide berriztagarriak erabiltzen badira. Europan nahiko ohikoak izan arren, Espainian ez dira horren ohikoak; beraz, hiri-instalazio gutxi daude, erabiltzen den energia-iturria edozein dela ere. Espainian, 2016 an 306 sare zeuden, eta horietatik ehuneko handi bat biomasaz elikatuta zegoen [41]; ikus 34. irudia.

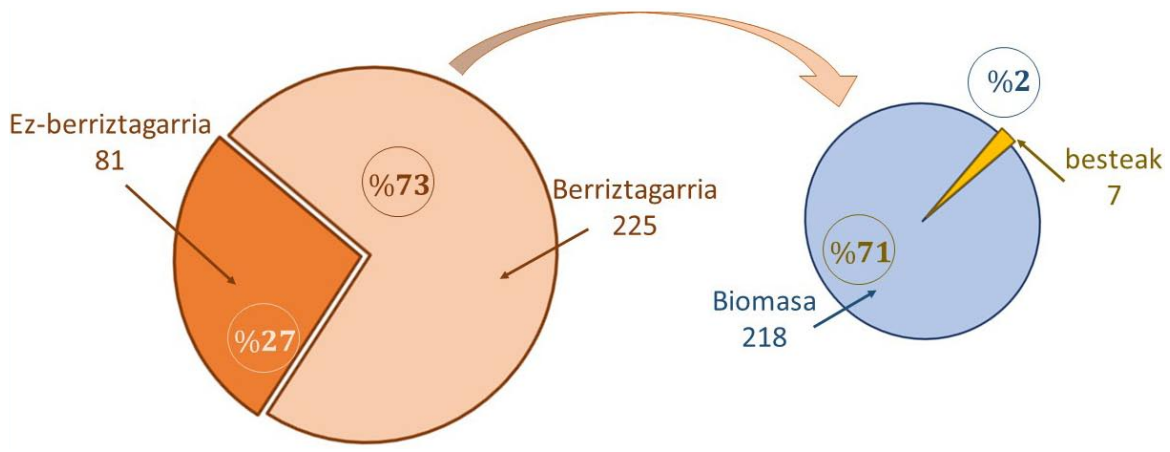

34. irudia. Espainian 2016an erroldatutako bero- eta hotz-sareak. 
Ana Picallo-Perez, Jose Maria Sala-Lizarraga, Arrate Hernandez-Arizaga

Hirietan eguzki-kolektoreak ekonomikoki bideragarriak ez badira, beste irtenbide bat bilatu behar da; hala ere, normalean, errazagoa da eguzki-kolektoreak eraikinen estalkietan jartzea [6].

\section{ONDORIOAK}

Energia-iraunkortasuna sustatu behar da klima-aldaketari aurre egiteko. Energia berriztagarriak aprobetxatzeko sistemak (eguzki-energia termikoa, esaterako) bultzatu behar dira, batez ere eraikuntza-sektorean, iturri fosilen menpekotasuna murrizteko, energia-faktura murrizteko eta $\mathrm{CO}_{2}$ isurketak murrizteko. Hala ere, gogoeta horiek gorabehera, eguzki-energia termikoa oso gutxi erabiltzen da Espainian, eta oraindik lan handia dago egiteke arlo horretan.

Lan honen ardatza da eguzki-kolektore termiko lauak aztertzea; munduan gehien erabiltzen direnak baitira, kostu txikia eta mantentze erraza daukatelako eta ekonomikoak direlako. Gainera, urtetik urtera, teknologia berri interesgarri anitz sortzen dira, material eta geometria berriekin, bero-hodien kolektoreekin, jariakin bero-eramaile berriekin eta kolektore hibrido pv-termikoen integrazioarekin.

Bestalde, gaur egun, kolektoreak eraikinen inguratzailean modu eraginkorrean integratzen direnez, errazagoa da energia berriztagarriak txertatzea. Horrela, errendimendua hobetzen da, ekonomia aldetik aurrezten da, eta eraikinaren eta ingurunearen artean interfaze homogeneoa osatzen da. Halaber, Espainian eguzki bidezko hozte-sistema eta klimatizazio-sareak aplikatzeko irtenbideak sustatu behar dira, eraikuntzan energia aurrezteko.

EKTren 2019ko araudi berria indarrean sartu denetik, eraikin guztiek energia-eraginkortasun handia lortu behar dute, eta, iturri berriztagarrien ekarpen handiagoa behar dute, energia-kontsumoa \% 40 murrizteko. DB-HE4 atalari dagokionez, Espainia osorako bateratu da UBS ekoizteko edota igerilekua girotzeko ekarpen berriztagarriaren ehunekoa, eta urteko eskariaren \% 70 gutxienez iturri-berriztagarrietatik ekoitzi behar da. Baldintza horiek nabarmentzen dute eguzki-teknologia berriak ikertu eta eraikinetan integratu beharra.

\section{ESKER ONAK}

Esker ona eman nahi zaie Eusko Jaurlaritzaren Etxebizitza Sailari, azken urteotako Etxebizitza zuzendariei, eta Eraikuntza Kalitatea Kontrolatzeko Laborategiari (EKKL). 


\section{BIBLIOGRAFIA}

[1] EUSKO JAURLARITZA. Gobierno Vasco. Departamento de Desarrollo Económico y Competitividad. Estrategia Energética De Euskadi 2030.

[2] TYAGI H, AGARWAL AK eta CHAKRABORTY PR. 2018. «Powar S. Introduction to applications of solar energy. In Applications of Solar Energy (pp. 3-10). Springer, Singapore.

[3] ESPAINIAKO GOBERNUA. Gobierno de España. 2017. Ministerio para la Transición Ecológica y el Reto Demográfico. Proyecto de ley de cambio climático y transición energética

[4] ESPAINIAKO GOBERNUA. Gobierno de España. 2017. Ministerio para la Transición Ecológica. La energía en España 2017

[5] IEA - International Energy Agency. www.iea.org

[6] INSTITUTO PARA LA DIVERSIFICACIÓN Y AHORRO DE LA ENERGÍA (IDAE) y la Asociación Solar de la Industria Térmica (ASIT). 2020. Guía IDAE 022. Guía Técnica de Energía Solar Térmica.

[7] $16^{\text {th }}$ EurObserv'ER Report. «The State Of Renewable Energies In Europe». Edition 2016

[8] ESPAINIAKO GOBERNUA. Gobierno de España. 2017. Ministerio para la Transición Ecológica y el Reto Demográfico. Impacto de la Energía Solar Térmica en la Calificación Energética de Edificios Estudios IDAE.

[9] COLANGELO G, FAVALE E, MIGLIETTA P eta DE RISI A. 2016. «Innovation in flat solar thermal collectors: A review of the last ten years experimental results ». Renewable and Sustainable Energy Reviews. May 1;57:1141-59.

[10] VERMA, S. K., GUPTA, N. K., eta RAKSHIT, D. 2020. «A comprehensive analysis on advances in application of solar collectors considering design, process and working fluid parameters for solar to thermal conversion ». Solar Energy, 208, 1114-1150.

[11] EHRMANN N eta REINEKE-KOCH NR. 2012. «Selectively coated high efficiency glazing for solar-thermal flat-plate collectors». Thin Solid Films;520:4214-8.

[12] BHOWMIK, H. eta AMIN, R. 2017. «Efficiency improvement of flat plate solar collector using reflector». Energy Rep 3, 119-123.

[13] CINDRELLA L. 2007. "The real utility ranges of the solar selective coatings ». Sol Energy Mater Sol Cells;91:1898-901.

[14] FERNÁNDEZ A eta DIESTE J-A. «Low and medium temperature solar thermal collector based in innovative materials and improved heat exchange performance ». Energy Convers Manag 2013;75:118-29.

[15] YOUCEF-ALI S. 2005. «Study and optimization of the thermal performances of the offset rectangular plate fin absorber plates, with various grazing». Renew Energy;30:271-80.

[16] EL-SAWI A-M, WIfi A-S, YOUNAN M-Y, ELSAYED E-A eta BASILY B-B. 2010. «Application of folded sheet metal in flat bed solar air collectors». Appl Therm Eng ;30:864-71. 
[17] OZGEN F, ESEN M eta ESEN H. 2009. «Experimental investigation of thermal performance of a double-flow solar air heater having aluminium cans ». Renew Energy;34:2391-8.

[18] PENG D, ZHANG X, DONG H eta LV K. «Performance study of a novel solar air col-lector ». Appl Therm Eng 2010;30:2594-601.

[19] ABENE A, DUBOIS V, LE RAY M eta OUAGUED A. 2004. «Study of a solar air flat plate collector: use of obstacles and application for the drying of grape ». J Food Eng;65:15-22.

[20] VERMA, S.K., SHARMA, K., GUPTA, N.K., SONI, P. eta UPADHYAY, N. 2020. «Performance comparison of innovative spiral shaped solar collector design with conventional flat plate solar collector». Energy. 194, 116853.

[21] AZAD E. 2008. «Theoretical and experimental investigation of heat pipe solar collector ». Experimental Thermal and Fluid Science ;32:1666-72.

[22] RASSAMAKIN B, KHAIRNASOV S, ZARIPOV V, RASSAMAKIN A eta ALFOROVA O. 2013. «Aluminum heat pipes applied in solar collectors». Solar Energy;94:145-54.

[23] DENG Y, ZHAO Y, WANG W, QUAN Z, WANG L eta YU D. 2013. «Experimental investigation of performance for the novel flat plate solar collector with micro-channel heat pipe array (MHPA-FPC)». Appl Therml Eng;54:440-9.

[24] RITTIDECH S eta WANNAPAKNE S. 2007. «Experimental study of the performance of a solar collector by closed-end oscillating heat pipe (CEOHP) ». Appl Therm Eng;27:1978-85.

[25] XUAN Y eta LI Q. «Heat transfer enhancement of nanofluid». Int J Heat Fluid Flow 2000;21:58-64.

[26] RAHMAN, M.M., MOJUMDER, S., SAHA, S., MEKHILEF, S. eta SAIDUR R. 2014. «Effect of solid volume fraction and tilt angle in a quarter circular solar thermal collectors filled with CNT-water nanofluid ». Int. Commun. Heat Mass Transfer, 57, 79-90.

[27] TRIPONAGNOSTOPOULOS Y. 2007. «Aspect and improvements of hybrid photovoltaic/ thermal solar energy systems ». Sol Energy;81:1117-31.

[28] BAZILIAN M-G, LEENDERS F, VAN DER REE B-G-C eta PRASAD D. 2001. «Photovoltaic cogeneration in the built environment ». Sol Energy;71:57-69.

[29] SALA-LIZARRAGA, JOSE M., eta ANA PICALLO-PEREZ. 2019. «Exergy Analysis and Thermoeconomics of Buildings: Design and Analysis for Sustainable Energy Systems ». Butterworth-Heinemann.

[30] X. ZHANG, X. ZHAO, S. SMITH, J. XU eta X. YU. 2012. «Review of R\&D progress and practical applications of the solar photovoltaic/thermal (PVT) technologies », Renewable and Sustainable Energy Review 16 599617.

[31] K. MORADI, M. ALI EBADIAN eta C.X. LIN. 2013. «A review of PVT technologies: effects and control parameters », International Journal of Heat and Mass Transfer 64 483-500. 

etxebizitzen eskariak asetzeko erabilera anitzeko iturri-berriztagarria

[32] N. ARCURI, F. REDA eta M. DE SIMEONE. 2014, «Photovoltaic thermal module concepts and their performance analysis: a review, Renewable and Sustainable Energy Review 14 1845-1859.

[33] HESTNES AG. 1999. «Building integration of solar energy systems». Solar energy. jan 1;67(4-6):181-7.

[34] REN G, ZHU Z, SUN Y eta ZHAO X. 2019. «Modular Solar System for Building Integration. In Advanced Energy Efficiency Technologies for Solar Heating, Cooling and Power Generation » (pp. 143-163). Springer, Cham.

[35] HAZAMI M, KOOLI S, LAZAAR M, FARHAT A eta BELGHITH A.2005. «Performance of a solar storage collector ». Desalination;183:167-72.

[36] MOTTE F, NOTTON G, CRISTOFARI C eta, CANALETTI J-L. «Design and modelling of a new patented thermal solar collector with high building integration». Appl Energy 2013;102:631-9.

[37] MATUSKA T eta SOUREK B.2006. Facade solar collectors. Sol Energy; 80:1443-52.

[38] JUANICO L. A 2008. «new design of roof-integrated water solar collector for domestic heating and cooling ». Sol Energy;82:481-92.

[39] VISA, I., DUTA, A., COMSIT, M., MOLDOVAN, M., CIOBANU, D., SAULESCU, R. eta BURDUHOS, B. 2015. «Design and experimental optimisation of a novel flat plate solar thermal collector with trapezoidal shape for facades integration ». Appl. Therm. Eng. 90, 432-443.

[40] GE, T. S., WANG, R. Z., XU, Z. Y., PAN, Q. W., DU, S., CHEN, X. M., eta CHEN, J. F. 2018. «Solar heating and cooling: Present and future development ». Renewable Energy, 126, 1126-1140.

[41] ADHAC, Asociación de Empresas de Redes de Calor y Frío, Censo Redes de Distrito, 2016. 
